\title{
Optimizing Stem Cell Therapy after Ischemic Brain Injury
}

\author{
Shuai Zhang, ${ }^{\mathrm{a}}$ Brittany Bolduc Lachance, ${ }^{\mathrm{b}}$ Bilal Moiz, ${ }^{\mathrm{a}}$ Xiaofeng Jia ${ }^{\mathrm{a}, \mathrm{c}, \mathrm{d}, \mathrm{e}, \mathrm{f}}$ \\ aDepartment of Neurosurgery, University of Maryland School of Medicine, Baltimore, MD, USA \\ 'Program in Trauma, Department of Neurology, University of Maryland School of Medicine, Baltimore, MD, USA \\ 'Department of Anatomy and Neurobiology, University of Maryland School of Medicine, Baltimore, MD, USA \\ dDepartment of Orthopedics, University of Maryland School of Medicine, Baltimore, MD, USA \\ eDepartment of Biomedical Engineering, Johns Hopkins University School of Medicine, Baltimore, MD, USA \\ fDepartment of Anesthesiology and Critical Care Medicine, Johns Hopkins University School of Medicine, Baltimore, MD, USA
}

Stem cells have been used for regenerative and therapeutic purposes in a variety of diseases. In ischemic brain injury, preclinical studies have been promising, but have failed to translate results to clinical trials. We aimed to explore the application of stem cells after ischemic brain injury by focusing on topics such as delivery routes, regeneration efficacy, adverse effects, and in vivo potential optimization. PUBMED and Web of Science were searched for the latest studies examining stem cell therapy applications in ischemic brain injury, particularly after stroke or cardiac arrest, with a focus on studies addressing delivery optimization, stem cell type comparison, or translational aspects. Other studies providing further understanding or potential contributions to ischemic brain injury treatment were also included. Multiple stem cell types have been investigated in ischemic brain injury treatment, with a strong literature base in the treatment of stroke. Studies have suggested that stem cell administration after ischemic brain injury exerts paracrine effects via growth factor release, blood-brain barrier integrity protection, and allows for exosome release for ischemic injury mitigation. To date, limited studies have investigated these therapeutic mechanisms in the setting of cardiac arrest or therapeutic hypothermia. Several delivery modalities are available, each with limitations regarding invasiveness and safety outcomes. Intranasal delivery presents a potentially improved mechanism, and hypoxic conditioning offers a potential stem cell therapy optimization strategy for ischemic brain injury. The use of stem cells to treat ischemic brain injury in clinical trials is in its early phase; however, increasing preclinical evidence suggests that stem cells can contribute to the down-regulation of inflammatory phenotypes and regeneration following injury. The safety and the tolerability profile of stem cells have been confirmed, and their potent therapeutic effects make them powerful therapeutic agents for ischemic brain injury patients.
Correspondence: Xiaofeng Jia Department of Neurosurgery, University of Maryland School of Medicine, 685 West Baltimore Street, MSTF Building 823, Baltimore, MD 21201, USA

Tel: +1-410-706-5026

E-mail: xjia@som.umaryland.edu https://orcid.org/0000-0003-14458525

Received: November 7, 2019

Revised: May 25, 2020

Accepted: June 17, 2020

Keywords Brain ischemia; Stem cells; Brain regeneration; Stem cell transplantation; Cardiac arrest; Stroke

\section{Introduction}

Decades of experimental evidence have shown the safety and efficacy of stem cell therapies in stroke animal models.' Despite promising outcome data from small, prospective, and phase I clinical studies, ${ }^{2,3}$ functional neurological outcomes from large randomized stem cell clinical trials have remained insufficient for supporting stem cell therapy in stroke patients, ${ }^{1}$ thus leaving 
a frustrating disconnection between the efficacy outcomes in preclinical versus clinical trials. ${ }^{4,5}$ This inconsistency suggests that many factors that remain unknown in ischemic brain injury may impact the stem cell effects. ${ }^{1}$ Translation of stem cell therapies from lab to patients requires a critical understanding of the different stem cell types and their mechanisms of action (i.e., cell replacement, growth factor secretion, exosome production, or inflammation regulation), ${ }^{6-8}$ as well as an in-depth exploration of the ideal route, timing of administration, and cellular modification. These factors need to be optimized for acute ischemic stroke and ischemic brain injury treatment.

Exogenous stem cell transplantation can improve the outcomes of patients with stroke $e^{8-15}$ and hypoxic-ischemic brain injury induced by cardiac arrest. ${ }^{16-18}$ Stem cell therapeutic benefits are not limited to their ability to replace diseased cells and tissues, but also extend to the provision of a supportive neurogenesis microenvironment over an extended period of time ${ }^{19}$ through bioactive neurotrophic factor secretion, ${ }_{1}^{20}$ mitochondrial transfer, ${ }^{8,21}$ and exosome release. ${ }^{7,22-25}$ Transplanted stem cells can also be used as delivery vectors for agents such as chemotherapeutics, pro-drugs, and cytokines that can mediate inflammatory responses. ${ }^{26-28}$

Despite the disappointing randomized controlled trial results, stem cell therapy remains a highly promising method to treat ischemic brain injury. Ischemic brain injury is defined as any injury to the brain caused by oxygen deprivation, such as ischemic stroke, perinatal hypoxic-ischemic encephalopathy (HIE), and cerebral ischemia secondary to cardiac arrest. We aim to summarize the work completed thus far, investigating stem cell sources, delivery routes, and methods for optimizing stem cell therapy, including survival and adhesion optimization. We will analyze this disconnection between preclinical and clinical outcomes, focusing on future directions for the clinical translation of this therapeutic intervention to promote its clinical application in ischemic brain diseases.

\section{Stem cell sources}

Stem cells belong to four major categories based on their differentiation potential (Figure 1). ${ }^{29}$ Totipotent cells, such as zygotes and early blastomeres, can generate the whole organism and represent a subset of stem cells with a huge differentiation potential; however, to date, these have not been successfully isolated and cultured in vitro. ${ }^{30}$ Pluripotent cells, such as embryonic stem cells (ESCs) and induced pluripotent stem cells (iPSCs), can differentiate into any tissue-specific adult body cell. ${ }^{30,31}$ Adult stem cells are multipotent and can differentiate into cell types within one particular lineage. ${ }^{31,32}$ Recently, unipotent stem cells, such as spermatogonial stem cells, have been found to be an important tissue maintenance and cellular regeneration source. $^{33}$

\section{Pluripotent stem cells}

ESCs and iPSCs have a powerful renewal potential and can be

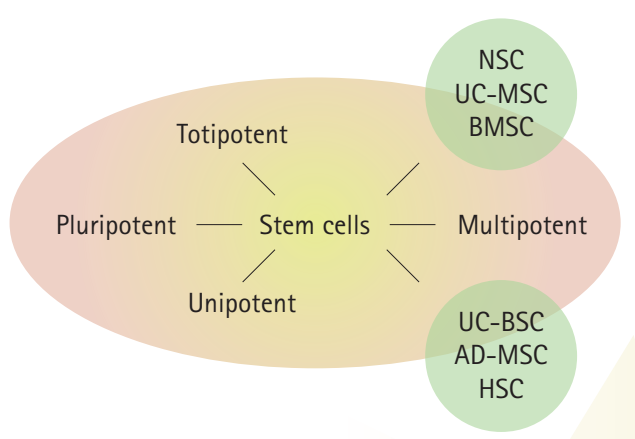

Stem cell pretreatment

Hypoxia

3D culture

Electrical stimulation

Stroke patient serum

Low oxidative stress

Chemical (metformin, minocycline)

Overexpression of VEGF, BDNF, FGF1

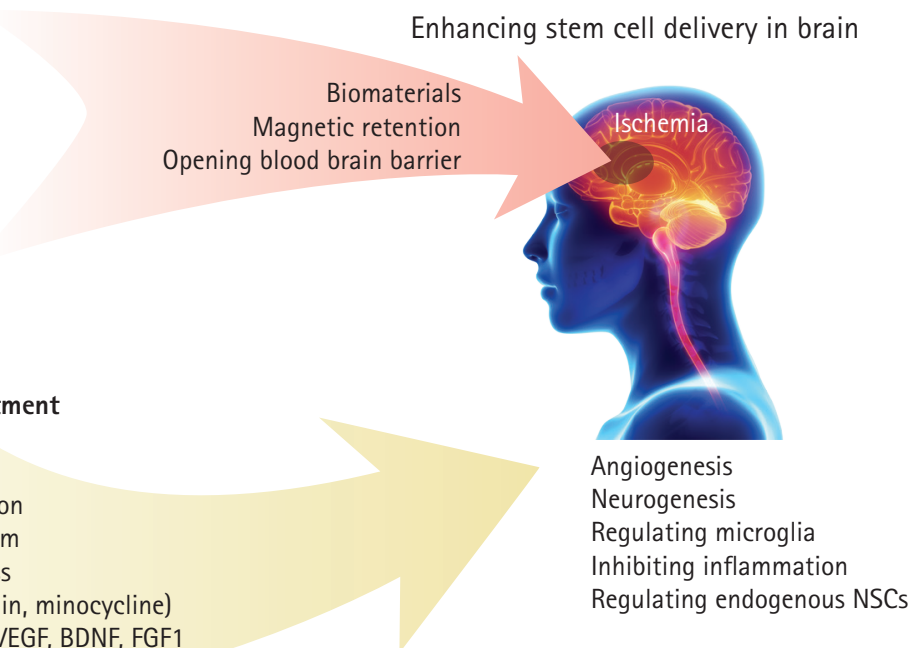

Enhancing stem cell function

Figure 1. Strategy for improving stem cell application in ischemic brain injury. NSC, neural stem cell; UC-MSC, umbilical cord-derived mesenchymal stem cell; BMSC, bone marrow stem cell; UC-BSC, umbilical cord blood stem cell; AD-MSC, adipose-derived mesenchymal stem cell; HSC, hematopoietic stem cell; 3D, three-dimensional; VEGF, vascular endothelial growth factor; BDNF, brain derived neurotrophic factor; FGF1, fibroblast growth factor type 1. 
manipulated to differentiate into phenotypes from all three embryonic layers. ${ }^{34}$ Human iPSCs (hiPSCs) have been used for therapeutic solutions regarding central nervous system (CNS) disorders, ${ }_{1}^{35}$ although their use for ischemic brain injury has remained limited. This cell type has been limited in translational use due to a potential risk for insertional mutagenesis or oncogenesis, production of immune-tolerable cells, and a poor integration into host circuits. ${ }^{34,36}$

\section{Neural stem cells}

Endogenous neural stem cells (NSCs) are primarily located in the sub-ventricular zone and dentate gyrus. Exogenous NSCs are extracted from three main sources for therapeutic purposes: direct extraction from brain tissue (particularly paraventricular or olfactory bulb regions), differentiation from pluripotent stem cells, and trans-differentiation from somatic cells, such as skin fibroblasts, renal tubular cells in urine, and blood cells. ${ }^{37}$ Initially, human NSCs held constraints: limited donor availability, low proliferation rate, and poor long-term in vitro expansion. It has recently been possible to culture them over several passages and successfully differentiate them into neuronal and glial cell types. ${ }^{38}$

Exogenous NSCs can migrate into ischemic brain areas, where they can differentiate into neurons or astrocytes and promote endogenous NSC proliferation and differentiation. ${ }^{39-41}$ Administration of human NSCs in a stroke rat model revealed neuroprotective effects by increasing dendritic branching, enhancing corticospinal tract projections, and inhibiting inflammation. ${ }^{42,43}$ Additionally, an in vitro and in vivo study has suggested that improved functional outcomes in stroke rats treated with transplanted NSCs may be associated with angiogenesis stimulation and brain microvasculature formation, due to the increased expression of proangiogenic factors in NSCs. ${ }^{44}$

A small phase I translational approach demonstrated that ipsilateral implantation of CTXOE3 human NSCs into the putamen of chronic stroke patients was safe, with no adverse events related to stem cell administration after 2 years of follow-up, and was associated with a slight improvement in the National Institutes of Health Stroke Scale (NIHSS). ${ }^{45}$ Notably, adverse events related to the invasive surgery required for therapy were reported.

Despite the promising utility of NSCs, some limitations exist. A very high cell dose is required for transplantation. Tissue-derived NSCs can clot in vivo, if transplanted at a high density, and may be prone to a poor survival rate. ${ }^{37}$ Further, our understanding remains limited about the molecular mechanisms regulating endogenous NSCs for neurogenesis and methods for enhancing endogenous neurogenesis in ischemic brain injury patients. ${ }^{46}$ More work is needed to optimize NSC application conditions prior to clinical practice.

\section{Mesenchymal stem cells}

Mesenchymal stem cells (MSCs) can be derived from a variety of sources, but are primarily harvested from the adipose tissue (AD-MSCs) or bone marrow (BM-MSCs). ${ }^{47}$ BM-MSC harvesting requires an invasive procedure and results in relatively low stem cell yields, whereas large quantities of AD-MSCs, which are easily accessible, abundant, and have little ethical concerns regarding their use, can be harvested using less-invasive liposuction techniques. ${ }^{20,48}$ MSCs are the most studied stem cell in stroke treatment, providing robust information for guiding stem cell application.

Preclinical studies demonstrate that transplantation of MSCs in an early stage of stroke improves neurological functional outcomes by regulating microglia phenotypes and stimulating regenerative processes. ${ }^{49,50}$ In cardiac arrest-induced brain injury, MSC administration, together with therapeutic hypothermia, can markedly enhance neuroprotection and reduce hippocampal neuronal death..$^{51}$ Unfortunately, MSCs are prone to accumulation and aggregation in other organs, particularly the lungs (up to $80 \%$ of cells), after intravenous (IV) administration, which may result in embolism or hemorrhage..$^{52,53}$

\section{Adipose-derived MSCS}

AD-MSCs display a homing tendency toward sites of brain injury, with neuroprotective effects in ischemic brain injury. ${ }^{48,54}$ Preclinical studies showed that topically-applied AD-MSCs onto the exposed parietal cortex in middle cerebral artery occlusion (MCAO) rodent models had neuro-modulatory abilities by activating microglia and promoting astrocytosis and cellular proliferation within 3 days, which was associated with an improved neurological recovery. ${ }^{55} \mathrm{~A}$ scaffold-free cell sheet allows implantation of a large number of AD-MSCs in the brain, which promotes angiogenesis, neurogenesis, anastomosis with the preexisting neurovascular unit, and behavior improvement in MCAO-induced rat stroke models. ${ }^{56}$

AD-MSCs are also an important exosome source. AD-MSCsecreted exosomes, a type of extracellular vesicle containing protein, DNA, and RNA, can decrease ischemia-induced neuronal cell death. 'Evidence shows that increasing miR-126 levels in the exosomes derived from AD-MSCs markedly improves functional recovery, promotes neurogenesis, and inhibits inflammation in stroke. The importance of exosomes in stroke recovery was also explored in an in vitro study that identified the importance of miR-181b-5p. It plays an important role in regulating its target molecule, transient receptor potential 
melastatin 7, which promotes mobility and angiogenesis of brain microvascular endothelial cells after oxygen-glucose deprivation exposure (OGD). ${ }^{57}$ Therefore, AD-MSCs are promising as an exogenous exosome delivery system for ischemic brain injury treatment.

\section{Bone marrow-derived MSCs}

IV injection of BM-MSCs, but not AD-MSCs, improved survival rates, anti-inflammatory cytokine levels, and growth factors in a neonatal hypoxic-ischemic brain injury rat model. ${ }^{52}$ BM-MSC administration protected the brain against ischemic injury after cardiac arrest and stroke by reducing inflammation, inhibiting the C-Jun $\mathrm{N}$-terminal kinase pathway, and releasing exosomes containing miR-138-5p. ${ }^{22,58-60} \mathrm{~A}$ translational phase I study of chronic stroke patients demonstrated the safety of intravenously transfused allogeneic, ischemia-tolerant BM-MSCs, as well as behavioral gains 1 year after treatment. This early study raised exciting potential for the application of this therapy in stroke. ${ }^{9}$ Allogenic or autologous BM-MSC administration to stroke patients improved behavioral and functional outcomes. ${ }^{49,61}$

\section{Umbilical cord blood stem cells}

Human umbilical cord blood stem cells (UC-BSCs) are derived from placental tissues, following birth. They consist of hematopoietic stem cells and MSCs. These cells offer a number of key advantages, such as an ample source of cells, low donor age, and low risks to babies and mothers during harvesting, which minimizes ethical concerns. These cells can differentiate into neural progenitor cells and provide neuroprotective effects in cerebral ischemia via neurotrophic factor secretion and vascular remodeling enhancement after stroke. ${ }^{62,63}$ UC-BSCs have protective effects against ischemic injury, resulting in brainderived neurotrophic factor expression recovery. ${ }^{64}$ In addition, UC-BSCs can inhibit the immune response and decrease the size of the ischemic brain lesion. ${ }^{65}$ These results indicate their potential in ischemic brain injury.

However, these cells have a key disadvantage: they do not cross the blood-brain barrier (BBB). ${ }^{6}{ }^{6}$ Interestingly, it was also noted that patients who underwent UC-BSCs transplantation were more prone to CNS infections. ${ }^{67}$

\section{Stem cell administration routes}

Following the decision regarding the stem cell source, the most suitable therapy delivery method must be defined, which is complicated by factors such as sufficient BBB traversal, diffusion through tissues, uptake speed, and specific targeting.

\section{Intravenous delivery}

IV delivery circumvents the need to access the CNS directly, thus allowing for less invasiveness. ${ }^{60,68}$ Intravenously injected NSCs can traverse the BBB and localize to ischemic injury areas. $^{39}$ NSCs, BM-MSCs, AD-MSCs, or UC-BSCs IV administration has shown neuroprotection in ischemic stroke. ${ }^{39,48,60,64,65,69}$

Despite these results, stem cells delivered by the IV route are subjected to trapping in peripheral tissues (lungs, liver, spleen, and kidneys), particularly the lungs, ${ }^{70}$ limiting cell delivery to the brain. Additionally, pulmonary embolism complications were noted in a Korean family following IV AD-MSCs administration. ${ }^{71}$ Cell size remains a major limiting factor in the intravenously delivered stem cell ability to traverse microvasculature or capillaries and avoid peripheral aggregation. Smaller cells, such as BM-MSCs (7 $\mu \mathrm{m}$ diameter), display up to a 30fold greater passing rate through the lungs compared to larger stem cell types, such as AD-MSCs $(18 \mu \mathrm{m})$ and NSCs (16 $\mu \mathrm{m}){ }^{70,72}$ Overall, it has been demonstrated that only a small number of cells reach the arterial system and target tissues, and that cells that get trapped in lungs can cause tissue damage. $^{73}$ In another study, IV BM-MSCs improved neurological function and restored BBB following damage from intracerebral hemorrhage. ${ }^{74}$ However, BM-MSCs preferentially migrated to the spleen, being detected at a modest level at 12 hours and 11 days following treatment. ${ }^{75}$ IV delivery of BM-MSCs in chronic stroke patients demonstrated an adequate safety profile. ${ }^{76}$ UC-BSCs tail vein injection also reduced infarct area and restored bladder function that had been impaired by cerebral ischemia in a rat stroke model. ${ }^{69,77}$

\section{Intra-arterial delivery}

Intra-arterial (IA) delivery uses catheterization to guide stem cells into the carotid artery or circle of Willis, thus bypassing the initial uptake by systemic organs. IA administration has been shown to be advantageous for MSC delivery at the site of injury. ${ }^{78-80}$ This delivery method allows for bypass of the lungs and avoids pulmonary entrapment. ${ }^{72}$ While this method delivers a large number of cells to brain lesions, it also carries a risk of micro-embolism and cerebral ischemia due to arterial cell aggregation and clumping, resulting in reduced cerebral blood flow. ${ }^{81-83}$ In clinical applications, injection of BM-MSCs, both IA (internal carotid artery) and IV, demonstrated safety and showed improved functional scores at 4 to 8 weeks post-therapy in chronic stroke patients. ${ }^{76}$

\section{Intraventricular delivery}

Intraventricular delivery allows for direct delivery into the cerebral spinal fluid (CSF) or interstitial tissue, thereby allowing 
the dispersal to multiple sites of the brain and CNS through the CSF. Despite the invasiveness of this technique, complications can be reduced with the proper training and technique. Intraventricularly injected BM-MSCs were transplanted into the lateral ventricles of cuprizone mice models, thereby initiating functional remyelination, oligodendrogenesis, and endogenous NSC proliferation through paracrine effects. ${ }^{84}$ Intrathecally-administered UC-BSCs could migrate to the ischemic area and differentiate into neurons and astrocytes, which improved motor function in stroke rats. ${ }^{85}$ Clinical applications of this method have supported the safety and potential efficacy, with improved neurological outcomes after intraventricular transplantation of BM-MSCs into patients with chronic sequelae of hemorrhagic stroke. ${ }^{86,87}$ In cardiac arrest-induced global brain ischemia, human NSC infusion into the lateral ventricle 3 hours following resuscitation significantly improved neurological and electrophysiological outcomes of rats. ${ }^{88}$

\section{Intraperitoneal}

Intraperitoneal (IP) administration of human MSCs (hMSCs) led to the rapid aggregation of cells in the peritoneal cavity, and only a small amount of cells migrated elsewhere. ${ }^{89}$ When compared to hMSC IV injection, IP administration resulted in a lower accumulation in peripheral tissues, such as the lungs and liver. However, IP-delivered umbilical cord-derived mesenchymal stromal cells (UC-MSCs) showed poor localization to the ischemic frontal cortex ${ }^{90}$ suggesting limited brain penetration.

\section{Intraparenchymal}

Localized intraparenchymal delivery allows for a higher cellular volume to reach brain target lesions, ${ }^{91}$ thereby preventing offtargeting effects and improving cost-effectiveness. Intracranial transplantation of human AD-MSCs was shown to promote neuronal repair in cerebral ischemia-reperfusion injury. ${ }^{54} \mathrm{MSC}$ intracranial injection has been used for neonatal hypoxic-ischemic brain injury. ${ }^{92}$ iPSC subdural injection upon infarcted brain tissue can reduce the infarct area size and improve motor function after ischemic stroke. ${ }^{93}$ Additionally, iPSC-derived NSC intracerebral transplantation was shown to differentiate into neurons and oligodendrocytes and improve recovery in a pig stroke model. ${ }^{94}$ UC-BSCs injected into the contralateral cortex could also migrate to the ischemic region of stroke rats. ${ }^{95}$ Despite these accomplishments, it remains controversial whether intracranial injections are feasible for clinical therapy. ${ }^{54,92,96} \mathrm{Di}-$ rect injection is invasive, as it requires a craniotomy, and this method can cause localized trauma and BBB damage. ${ }^{97}$ The required surgery for this delivery method can potentially disrupt local niches and result in additional traumatic injury and in- flammation. Intraparenchymal delivery is also ineffective at addressing multifocal disorders; thus, its feasibility for clinical translation is still debatable. ${ }^{96}$

\section{Intranasal delivery}

Intranasal administration is a noninvasive and relatively effective drug or cell delivery route when compared to invasive intracranial transplantation. Although it has been recognized as a small agent (e.g., small molecules, proteins, viruses, bacteria, and nanoparticles) delivery method, its utility for cellular delivery has only been discovered in the last decade. ${ }^{98}$ Intranasallydelivered cells collect beneath the nasal mucosa, close to the turbinate bones, and travel through the cribriform plate. ${ }^{99}$ This method of delivery is non-invasive, rapid, and offers BBB bypass. ${ }^{100}$ Cells showed improved targeting and less accumulation in peripheral organs, compared to systemic dosage. ${ }^{101}$ Additionally, intranasal delivery allows for repeated dosages, ${ }^{102-105}$ making it more practical than other methods.

Both MSCs and NSCs have been shown to be effective agents in intranasal cell therapy. ${ }^{102,106}$ Intranasal delivery of hypoxiapreconditioned BM-MSCs in a rat stroke model demonstrated significantly reduced cell death in peri-infarct regions. ${ }^{107}$ Intranasal MSC treatment of neonatal hypoxic ischemic-injured mice has demonstrated long-term cognitive and sensorimotor improvement. ${ }^{105}$ Furthermore, a single intranasal dose was sufficient for therapeutic benefits, while at least two intracranial dosages were required to achieve the same effect. Intranasallyadministered NSCs to HIE neonatal rats showed substantial migration into the brain 24 hours post-delivery and improved functional neurological outcomes. ${ }^{108}$ In stroke, BM-MSC intranasal delivery provided neuroprotection, enhanced neurovascular regeneration, and led to improved functional recovery. ${ }^{63,103,109}$

It is important to recognize that the clinical translation of this method remains poorly understood. Humans have a smaller olfactory bulb compared to that in the rodents utilized in these preclinical studies, and it remains unclear if this difference can hinder the translational potential of intranasal administration. Of note, a hypoxic-ischemic brain injury neonatal primate model demonstrated migration of intranasally delivered MSCs to the site of injury, suggesting a feasible translation. ${ }^{96}$

Overall (Table 1) ${ }^{42,45,51,77,78,81,82,84,90,91,100,102-105,110}$ IV, intracerebral, and IA routes have been the most utilized and investigated for stem cell administration in preclinical and clinical studies. IV administration facilitates widespread implementation and avoids invasive procedures, but reduces brain tissue penetration due to cell diffusion and risks accumulation in other organs such as the liver, spleen, and lungs. ${ }^{111}$ Intracerebral injection has high therapeutic benefits, but with invasive risk. Con- 
Table 1. Advantages and disadvantages of different stem cell administration routes

\begin{tabular}{|c|c|c|c|}
\hline Routs & Advantage & Disadvantage & Reference \\
\hline Intravenous & Low invasiveness & $\begin{array}{l}\text { Trapping in peripheral tissues, particularly lung; } \\
\text { pulmonary embolism }\end{array}$ & $42,51,77$ \\
\hline Intra-arterial & $\begin{array}{l}\text { Low pulmonary entrapment } \\
\text { Increasing stem cell delivery to brain }\end{array}$ & Microvascular occlusion & $78,81,82$ \\
\hline Intraventricular & Allow for delivery to multiple sites of the CNS & Invasiveness & 84 \\
\hline Intraperitoneal & $\begin{array}{l}\text { Low pulmonary entrapment } \\
\text { Low invasiveness }\end{array}$ & Limited brain penetration & 90,110 \\
\hline Intraparenchymal & $\begin{array}{l}\text { Directly targeting injured brain region } \\
\text { Prevention of off-targeting effects }\end{array}$ & $\begin{array}{l}\text { Invasiveness } \\
\text { Trauma and BBB damage of injection location }\end{array}$ & 45,91 \\
\hline Intranasal & $\begin{array}{l}\text { Noninvasive } \\
\text { Direct migration to brain } \\
\text { Repeated dosages }\end{array}$ & Lacking clinical evidence & $100,102-105$ \\
\hline
\end{tabular}

CNS, central nervous system; BBB, blood-brain barrier.

versely, the IA route has better CNS penetration and bypasses other organ systems, but has associated arterial micro-embolism and cell-aggregation risks. ${ }^{111}$ Intranasal delivery, a minimally invasive novel delivery mechanism, may be an optimal route in the future, but technical aspects, such as administration technique, cell type, position of head during administration, and volume of dosage should all be considered, requiring further investigation in clinical application.

\section{Improvement of stem cell application in ischemic brain injury}

Multiple factors influence cell transplantation efficacy and treatment outcomes. Ideally, stem cells used in the treatment of CNS disorders need to be highly manipulated, to be integrated into the host tissue, and should be able to traverse the BBB. ${ }^{112-}$ ${ }^{114}$ They must overcome the limitations of scarce donor sources, uncontrolled cell maturity, poor cell survival, inefficient delivery, and low engraftment rate ${ }^{115}$ prior to their utilization as a viable clinical therapy. A major difficulty within stem cell therapy is the inability to maintain cell viability, properties, and functions before and after in vivo implantation. This can lead to low cell survival rates and poor outcomes in growth, homing, differentiation, and paracrine effects. ${ }^{116}$ To overcome these obstacles, methods such as stem cell modification, pretreatment, and chemical or biomaterial assistance, have been used to enhance stem cell therapy and promote its clinical application.

\section{Optimal dose, timing, and age of stem cells}

Two essential parameters that can be optimized in the use of stem cells in ischemic brain injury include the number of delivered cells and the timing of delivery. A density ranging from
$5 \times 10^{3}$ to $2 \times 10^{7}$ MSCs has been studied in animals, typically intravenously, immediately following ischemic stroke or over a period typically varying from 24 hours to 30 days. ${ }^{111}$ Preclinical studies indicate that IV doses ranging from $3.6 \times 10^{4}$ to $4.3 \times 10^{7}$ $\mathrm{MSC} / \mathrm{kg}$ body weight provide substantial behavioral gains in rodents. ${ }^{117}$ An additional study noted a significant lesion size reduction and sensorimotor function improvement when $0.5 \times 10^{6} \mathrm{MSC}$ were delivered per mouse in a neonatal hypoxicischemic model. They noted that decreasing the dose to $0.25 \times 10^{6}$ MSCs did not have a significant effect on sensorimotor performance or gray/white matter preservation, while increasing the dose to $1.0 \times 10^{6}$ did not result in additional improvements to sensorimotor function or lesion size reduction. ${ }^{105}$ Translationally, IV transfusion of $0.5,1.0$, and $1.5 \times 10^{6}$ allogeneic BM-MSCs/kg body weight was shown to be safe in a phase I trial and suggested behavior gains in chronic stroke patients. ${ }^{9}$ UC-BSCs $\left(2 \times 10^{6}\right.$ cells per rat) showed safety and neuroprotection in stroke rats after IV administration 2 days following ischemia induction. ${ }^{77}$ Additionally, IV injection of UCBSCs $\left(1 \times 10^{6}\right.$ or $\left.4 \times 10^{6}\right), 1$ day after ischemic injury, has been shown to reduce neurological injury in stroke rats. ${ }^{118}$

Regarding timing, MSCs administered 3 or 10 days postneonatal hypoxic ischemic injury showed significant improvements in motor behavior, while administration at 17 days showed neither sensorimotor function improvement nor gray/ white matter loss reduction. This suggests a broader treatment window for intranasal MSC delivery, particularly when compared to the current treatment window of 6 hours for therapeutic hypothermia, which is the current standard of care. ${ }^{105}$ In another study, hypoxic-preconditioned BM-MSCs were intranasally delivered 3, 4, 5, and 6 days after ischemic stroke in mice. These cells reached the brain 6 hours after delivery, 
where they increased neurogenesis, angiogenesis, and local cerebral blood flow when measured 21 days after stroke. Functional recovery was improved in these animals. This study highlighted that repeated administration of stem cells 3 to 6 days after stroke could be beneficial, thus extending the therapeutic window for stroke beyond the current 24-hour limitations. ${ }^{103}$ BM-MSCs administration between 2 and 7 days of injury significantly increased health benefits compared to 12 to 24 hours and $>7$ days. ${ }^{119}$ Delivery at 7 days post-stroke has been most commonly reported in the literature, which may be related to the specific brain environment at that time, with decreased glutamate and brain edema. ${ }^{120}$ After stroke, the brain microenvironment is constantly changing, with increased excitotoxicity, inflammatory reaction, and trophic factor expressions. ${ }^{120}$ Immediately following ischemic insult, ischemia-reperfusion events occur, including cellular energetic failure, mitochondrial $\mathrm{Ca}^{2+}$ overload, oxidative stress, BBB dysfunction, inflammation, apoptosis, and eventual neuron and glial cell necrosis, ${ }^{121,122}$ which may block or interfere with the transplanted stem cells' neuroprotective effects. Thus, the pro-regeneration environment in the ischemic area around the 7-day time point may be considered as the optimal time point for stem cell delivery. Compared with ischemic stroke, brain injury induced secondary to cardiac arrest has different conditions related to stem cell treatment (Table 2). 10,16-18,51,123-127 To date, BM- and AD-MSCs are the most commonly used stem cells in this pathology, and the cells are typically administered 1 to 2 hours after the return of spontaneous circulation. After 1 hour of brain ischemia, the subdural transplantation of iPSCs $\left(1.0 \times 10^{6}\right)$ is found to improve recovery in stroke rats. ${ }^{93}$ Recently, our lab reported that intraventricularly administered hNSCs 3 hours after 8-minute asphyxia-cardiac arrest significantly improved neurological outcomes. ${ }^{88}$ However, an optimal stem cell delivery timing has not been fully elucidated regarding this pathology, and additional studies are needed to provide further evidence for optimal time point of stem cell delivery and timedependent pathophysiologic changes of the brain after cardiac arrest. Available preclinical studies indicate that IV doses ranging from $1 \times 10^{6}$ to $5 \times 10^{6}$ cells provide substantial behavioral

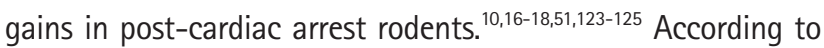
the allometric scaling approach from animals to humans recommended by the Food and Drug Administration, the equivalent MSC dose in humans is about $1.6 \times 10^{6} \mathrm{MSCs} / \mathrm{kg}^{9}{ }^{9}$

The hMSC donor age is another critical factor affecting functional and structural outcomes in stroke affecting functional and structural outcomes in stroke. ${ }^{128,129}$ MSCs from older donors have a decreased proliferative capacity and trophic factor secretion. ${ }^{130}$ Autologous transplantation has been suggested as a safe therapy with minimal immune consequences. However, stroke patients tend to be older, which limits the proliferation potential of their autologous stem cells and limits this mode of therapy in this particular pathology.

Stem cell dosage and timing remain to be optimized, both to avoid complications, such as vessel embolism and local energy deficiency, and to optimize transplanted cell survival, differentiation, and function. To achieve this, stem cell interactions

Table 2. Stem cell therapy application in cardiac arrest-induced brain injury

\begin{tabular}{|c|c|c|c|c|c|c|c|}
\hline Cell type & Precondition & Number & Volume & Transplantation route & Administration time & $\begin{array}{l}\text { Exposure } \\
\text { time }\end{array}$ & Reference \\
\hline BMSCs & $\begin{array}{r}\text { Overexpression of } \\
\text { BDNF and VEGF }\end{array}$ & $3 \times 10^{6}$ & $500 \mu \mathrm{L}$ PBS & Jugular vein injection & $2 \mathrm{hr}$ after ROSC & 7 day & 17 \\
\hline ADSCS & & $5 \times 10^{6}$ & $1 \mathrm{~mL}$ PBS & Intravenous & $1 \mathrm{hr}$ after ROSC & $1,3,7$ day & 10 \\
\hline BMSCs & & $1 \times 10^{6}$ & $0.5 \mathrm{~mL}$ PBS & Tail vein injection & $1 \mathrm{hr}$ after ROSC & $1,3,7$ & 18 \\
\hline ADSCS & & $1 \times 10^{6}$ & & IV & Immediately after ischemia & 7 day & 55 \\
\hline MSCs & $\begin{array}{l}\text { Hypoxia precondition } \\
\qquad\left(1 \% \mathrm{O}_{2}\right)\end{array}$ & $4 \times 10^{7}$ & $0.5 \mathrm{~mL}$ PBS & Jugular vein injection (>15 min) & $1 \mathrm{hr}$ after ROSC & $1,3,7$ day & 126 \\
\hline BMSCs & & $5 \times 10^{6}$ & $0.5 \mathrm{~mL}$ PBS & Right atrium & $2 \mathrm{hr}$ after ROSC & $1,3,7$ day & 125 \\
\hline BMSCs & & $5 \times 10^{6}$ & $0.5 \mathrm{~mL}$ PBS & Right atrium & $2 \mathrm{hr}$ after ROSC & 8 day, 5 wk & 16 \\
\hline RUCM cells & & $1 \times 10^{4}$ & $\begin{array}{l}2.5 \mu \mathrm{L} \text { each } \\
\text { site }\end{array}$ & $\begin{array}{l}\text { Intracerebral injection dorsal thalamic } \\
\text { Nucleus, dorsal hippocampus, corpus } \\
\text { callosum, dorsal cortex }\end{array}$ & 3 day prior to $\mathrm{CA}$ & 3 day & 127 \\
\hline iPSC-MSCs & & $2.5 \times 10^{6}$ & $0.5 \mathrm{~mL}$ PBS & Femoral vein & ROSC success & 1 day & 124 \\
\hline ADSCs & & $1 \times 10^{6}$ & $\begin{array}{l}1 \mathrm{~mL} \text { of } 0.9 \% \\
\text { saline }\end{array}$ & $\begin{array}{l}\text { Femoral } \\
\text { Venous }\end{array}$ & ROSC success & 7 day & 123 \\
\hline
\end{tabular}

BMSC, bone marrow stem cell; BDNF, brain derived neurotrophic factor; VEGF, vascular endothelial growth factor; PBS, phosphate-buffered saline; ROSC, return of spontaneous circulation; ADSC, adipose-derived stem cell; IV, intravenous; MSC, mesenchymal stem cells; RUCM, rat umbilical cord matrix; CA, cardiac arrest; iPSC, induced pluripotent stem cell. 
with the dynamic microenvironment in the ischemic brain must be further understood. Stem cell therapy should be considered according to the delivery routes, stem cell types, and quality, progress of disease, and age of patients for optimal translation in dose, timing, and cell age.

\section{Stem cell preconditioning}

\section{Hypoxic preconditioning}

Stem cell hypoxic preconditioning has been shown to increase cell survival and promote angiogenesis and neurogenesis. ${ }^{131}$ It also improves MSCs homing and neuroprotective ability. ${ }^{79,98}$ Under low-oxygen (5\%) culture conditions, MSCs have a higher proliferation rate, cytokine secretion, and migration activity. ${ }^{132,133}$ Hypoxic-preconditioning of BM-MSCs enhances cell homing and increases regeneration and functional recovery after ischemic stroke. ${ }^{75,107}$ In vitro, hypoxia conditioning improves the protective efficacy of aged human BM-MSCs in OGD-induced neuronal injury by increasing the secretion of vascular endothelial growth factor (VEGF). ${ }^{15}$ Hypoxia-preconditioned MSCs in vivo transplantation promotes MSC migration and integration and decreases neuronal death in cardiac arrest-induced ischemic brain injury. ${ }^{126}$

\section{Bioactive factor overexpression}

Enhancing the expression of specific trophic factors is an important method for stem cell modification. Mechanistic analysis suggests that MSCs' therapeutic efficacy against neurologic disorders may be mediated by VEGF and brain derived neurotrophic factor (BDNF) secretion. 134,135 Further evidence shows that both BDNF and VEGF overexpression in BM-MSCs markedly enhances neuroprotective potency from cardiac arrest-induced global cerebral ischemia one week after cell transplantation. ${ }^{17}$ Increasing the expression of glial cell line-derived neurotrophic factor (GDNF) in UC-BSCs markedly elevates GDNF level in the infarcted hemisphere and enhances stroke rats' functional recovery. ${ }^{136}$

Fibroblast growth factor type 1 (FGF1) is abundant in sensory and motor neurons and binds to FGF receptors, which contributes to neuroprotection mediated by autocrine, paracrine, and intracrine pathways. ${ }^{137,138}$ In vitro FGF1 (100 ng/mL) exposure can promote neurite outgrowth of cortical neurons, and application of FGF1 ( 1 or $2 \mu \mathrm{g}$ ) in the brain injured area improves neuroprotective effects in a cerebral ischemic rat model. ${ }^{139}$ Acute IV administration of $2 \times 10^{6}$ FGF1-overexpressed ADMSCs was shown to improve functional neurological recovery and mildly reduce infarct volume in a stroke rat model. ${ }^{140}$

A novel optochemogenetics fusion protein, luminopsin 3 , can be activated by either extrinsic physical light (i.e., laser and light-emitting diode) or by the luciferase substrate coelenterazine. Stimulation of luminopsin 3 and iPSC-derived neural progenitor cells increases synapsin-1, postsynaptic density 95 , BDNF, and stromal cell-derived factor 1 expression. Focal ischemic stroke mice receiving the combined luminopsin 3-iPSCneural progenitor cells (NPCs)/coelenterazine treatment possess enhanced neural network connections in the infarct region, thereby promoting optimal functional recoveries. ${ }^{14}$

\section{Chemical treatment}

Previous reports indicate that metformin is an optimal neuroregenerative agent, acting on multiple stages, such as proliferation (dependent on the p53 family member and transcription factor TAp73), differentiation (activating the AMP-activated protein kinase [AMPK]-atypical protein kinase C [aPKC]-CREBbinding protein [CBP] pathway), and cell survival. ${ }^{141,142}$ Metformin, a known AMPK activator, has neuroprotective effects for stroke treatment and prevention. IP injection of metformin (50 $\mathrm{mg} / \mathrm{kg}$ ) prior to stroke for 3 weeks improved stroke-induced lactate generation and ameliorated mouse stroke injury. ${ }^{143}$ Moreover, rats preconditioned with metformin (10 mg/kg, IP), prior to inducing ischemia, had reduced apoptotic cells in the peri-infarct region. ${ }^{144}$ Metformin $(50 \mu \mathrm{M})$-preconditioned iPSCNSCs promote post-stroke recovery by enhancing hiPSC-NSC proliferation, differentiation, and engraftment. ${ }^{145}$

Minocycline, a semisynthetic tetracycline, also has a neuroprotective potential in cerebral ischemia. Treatment with minocycline ( $45 \mathrm{mg} / \mathrm{kg}$ IP twice a day for the first day; $22.5 \mathrm{mg} / \mathrm{kg}$ for the subsequent 2 days) before or after ischemia has been shown to reduce the infarct size in the cerebral cortex, and minocycline therapy has a wide therapeutic window. ${ }^{146}$ Minocycline treatment $(10 \mu \mathrm{M})$ increases NSC proliferation capacity, and minocycline preconditioning induces NSCs to release paracrine factors, including BDNF, GDNF, nerve growth factor, and VEGF. ${ }^{147}$ In addition to the anti-inflammatory effects in ischemic brain injury, ${ }^{148}$ minocycline preconditioning can also improve NSC survival after exposure to ischemic reperfusion injury via nuclear factor erythroid 2-related factor 2 (Nrf2) and heme oxygenase-1 upregulation. ${ }^{147}$

CD34+ UC-BSCs pre-treated with $17 \beta$-estradiol were shown to reduce the infarct size at 2 hours and 2 days in a rat stroke model. This pretreatment also improved cerebral blood flow at 2 hours and reduced hyperperfusion at 2 days. This study was performed in female ovariectomized rats with a proposed mechanism of stabilization of cerebral hemodynamics and BDNF expression regulation. ${ }^{64}$ 


\section{Others}

Short-term exposure to oxidative stress at low concentrations has been shown to improve NPC resistance to acute stress. ${ }^{149}$ Three-dimensional (3D) stem cell aggregates can also precondition cells by increasing extracellular matrix secretion and promoting trophic functions. ${ }^{131}$ Electrically preconditioned NPCs with a conductive polymer scaffold improved functional outcomes compared to unstimulated cells in stroke. ${ }^{150}$ Stroke patients' serum from the acute phase of stroke can activate MSCs, and markedly promote neurogenesis and angiogenesis. ${ }^{151} \mathrm{Ulti}-$ mately, preconditioning has been shown to result in a suppressed immune response, increased regeneration, enhanced migration and paracrine effects, and increased treatment efficacy. ${ }^{152}$

Overall, to enhance stem cell-mediated neuroprotection in stroke, preconditioning of stem cells with hypoxia, electrical stimulation, chemicals, or neurotrophic factor overexpression might be an important strategy for their future clinical application (Figure 1). These preconditioning methods were majorly based on mechanisms of stem cell therapy in stroke. Thus, it is significant to clarify the molecular modulation of stem cells in neuroprotection, which may lead to the discovery of more preconditioning methods.

\section{Combination approaches}

In cardiac arrest-induced brain injury, MSC-treated rats exhibit better or equivalent functional outcomes, compared to rats treated immediately with therapeutic hypothermia $\left(32^{\circ} \mathrm{C}\right.$ to $34^{\circ} \mathrm{C}$ ) for 2 hours after ischemia, although hypothermia was not found to markedly enhance MSC therapy benefits in this pathology. ${ }^{51}$ However, in ischemic stroke rats, post-ischemia hypothermia induced by injection of cold saline $\left(4^{\circ} \mathrm{C}\right)$ via carotid artery at an infusion rate of $0.6 \mathrm{~mL} / \mathrm{min}$ for 5 minutes can enhance the therapeutic effects of MSC on reperfusion injury. ${ }^{153}$

Seven days after ischemia induction, the combined utilization of UC-BSCs (injection once via the tail vein) and erythropoietin (IP exposure for 5 consecutive days) was shown to have strong neurogenic and angiogenic effects in stroke rats. ${ }^{154} \mathrm{Fi}-$ brin glue, a biocompatible and biodegradable natural product, combined with iPSCs enhanced stoke-induced deficits recovery. The fibrin glue may also increase iPSCs utilization safety. ${ }^{93}$

Cerium oxide nanoparticles can bind to oxygen molecules and may scavenge intracellular reactive oxygen species. ${ }^{155} \mathrm{Hy}$ aluronic acid-cerium oxide-labeled human umbilical cord MSCs gain combined antioxidant and anti-inflammatory effects, and significantly attenuate stroke injury. ${ }^{156}$

\section{Enhancement of stem cell delivery in brain}

\section{Increasing BBB permeability}

Mannitol, a hyperosmolar extracellular agent often used to control intracranial pressure following brain injury, may serve as a useful agent to increase BBB permeability. Coupling intravenously delivered UC-BSCs with mannitol to facilitate the entry of therapeutic biologics into the brain showed improved neuroprotection when compared with UC-BSCs alone. ${ }^{66}$ The combination drug treatment of mannitol and temozolomide increases BBB permeability through the inhibition of endothelial tight junction proteins, and allows for the efficient delivery of UC-MSCs microvesicles into the brain in a chronic stroke rat model. ${ }^{157}$ Focused ultrasound, in combination with magnetic fields, can also enhance stem cell delivery by selectively opening the BBB at specific predetermined locations. ${ }^{158}$

\section{Biomaterials}

Biomaterials systems continue to play an increasingly important role in regenerative medicine, particularly alongside stem cell usage. They can be used to form scaffolds that encapsulate growth factors and cells in order to protect and shield them from unfavorable in vivo environments, while sequestering factors to promote an optimal regenerative environment. ${ }^{159}$ Encapsulation also prevents in vivo immune response activation and inflammation. ${ }^{131}$ Additionally, these scaffolds may intrinsically contain properties that can provide cues to stem cells such as matrix topology, mechanical forces, and biochemical properties. ${ }^{160}$ For example, various studies have demonstrated that softer substrates can promote neurogenic differentiation in NSCs, while stiffer substrates will instead direct them towards astrocyte differentiation. ${ }^{161}$ This highlights the need to optimize these biomaterials for stem cell viability, differentiation, and proliferation. A recent meta-analysis found that biomaterialbased interventions have led to lesion volume reduction and improved neurological outcomes in stroke rodent models. ${ }^{162}$

Hydrogels act as 3D scaffolds that improve stem cell survival and differentiation, both in vivo and in vitro. ${ }^{163}$ However, they must be finely engineered for optimal cell delivery. Gels that solidify too quickly can get clogged in a needle during delivery. However, if they solidify too slowly, the therapeutic agent may diffuse out of target sites, thus resulting in suboptimal therapy. ${ }^{164}$ Injectable chitosan self-healing hydrogels mixed with murine NSCs were synthesized to address this issue and showed promise for CNS injury. Chitosan is a nontoxic biodegradable substrate that can promote nerve regeneration. The authors found that neurosphere progenitors grew twice as fast in selfhealing hydrogels and had a greater tendency to differentiate 
into neuron-like cells. ${ }^{164}$ Another study demonstrated that matrigel scaffolding plus neuronal precursor cell injection into the infarct cavity could improve the functional outcome, with notable effects several weeks after initial stroke injury. ${ }^{165} \mathrm{Neu}$ roepithelial progenitor cells encapsulated in a hyaluronan-based hydrogel showed facilitated injection of the cells into the brain and reduced inflammatory response in the stroke-injured rodent brain. ${ }^{163}$ Injectable hydrogels composed of hyaluronan acid and methylcellulose were demonstrated to improve the survival and integration of stem cells following transplantation in stroke injury murine models. ${ }^{166}$ Methylcellulose promotes neuron regeneration through axon connections, while hyaluronan acid promotes angiogenesis and cell proliferation. ${ }^{167}$ The bioactive materials that compose this hydrogel provided survival factors that enhanced NSC distribution and survival in the brain via CD44mediated mechanisms and inhibited apoptosis. ${ }^{168}$ Injection of a biopolymer hydrogel, together with neural progenitor cells, into the infarct cavity after stroke was shown to significantly enhance the survival of transplanted cells and diminish inflammatory response. ${ }^{169}$ Post-polymerization modification of methionine-based co-polypeptides demonstrate tunable properties that aid in vivo transplantation of neural stem/progenitor cells in the CNS. In the absence of growth factors, these hydrogels preserved the transplanted cells and facilitated local axon regrowth, retained transplanted cells close to the injection site, and allowed integration into the host neural tissue. ${ }^{170}$

\section{Stem cell magnetic retention in target location}

Magnetic cell targeting can guide cells to sites of injury to overcome stem cell retention limitations after intra-carotid or IV delivery. Human neuro-progenitor cells labeled with ultrasmall superparamagnetic iron oxide nanoparticles were used to increase efficacy and retention at the site of traumatic brain injury (TBI) in rats. Labeled cells did not exhibit any modifications in viability, proliferation, or differentiation, thereby suggesting that neither nanoparticles nor magnetic fields are disruptive to the intrinsic behaviors of the cell. ${ }^{158}$ This method of enhanced targeting remains to be applied to ischemic brain injury, but its efficacy in TBI shows promise for other brain pathologies (Figure 1).

In summary, stem cell therapeutic strategies include the enrichment of stem cells in the brain, stem cells engineered with biomaterials, and stem cell control with magnetism in an effort to overcome the weaknesses of stroke stem cell therapy. Stem cell engineering has facilitated an enhanced docking ability in the endothelium within the ischemic core. Magnetic retention of stem cells is promising to target the location of ischemic injury within the brain. Stem cell lineage differentiation induced by chemicals or biological factors may contribute to tissue regeneration in the stroke infarct bed. More methods, such as the combination of various stem cells, biomaterials, genetic, and chemical modifications, may emerge in future studies to enhance stem cell therapy in stroke and global cerebral ischemia.

\section{Stem cell tracking}

To track the transplanted cells, stem cells are labeled with probes such as fluorophobes (4',6-diamidino-2-phenylindole [DAPI], PKH26 [red fluorescent dye], or 5-bromo-2'-deoxyuridine $[\mathrm{BrdU}])_{1}{ }^{16,125,126}$ radiotracers, or paramagnetic nanoparticles before transplantation, and are then monitored in vivo using optical imaging, single photon emission computed tomography (SPECT), positron emission tomography (PET), or magnetic resonance imaging (MRI). ${ }^{171}$ Two pitfalls of direct labeling include dilution of the labeling agent with proliferation of originally-labeled cells and in vivo uptake of probes by phagocytic cells. Indirect methods of tracking consist of exogenous reporter genes that have been delivered to the cells of interest, such as ferritin heavy chain, which can act as robust MRI reporters to track cell distribution and migration for acute ischemic stroke. ${ }^{172}$ Since only surviving cells take up the reporter, viable cells can be clearIy visualized. However, gene delivery may disrupt normal cell physiology. ${ }^{173}$

Direct tracking via MRI provides advantages, such as morphology characterization, high spatial resolution, lack of radiation, and long-term stem cell monitoring. ${ }^{174,175} \mathrm{MRI}$ requires the use of a contrast agent to visualize cells, e.g., superparamagnetic iron-oxide nanoparticle (SPION), which has been shown to allow in vivo retention of neural progenitor cell viability, phenotype, proliferation, and differentiation. ${ }^{176,177}$ Highspeed MRI has been used to visualize IA delivery of SPION-labeled stem cells in both control and stroke animal models. Real-time feedback allowed for accurate spatial and temporal distribution information. It also allowed cell infusion speed to be optimized in response to vascular resistance. This method also provided information on stem cell delivery efficacy, destinations and off-target routes, adherence, and aggregation. ${ }^{178}$ Long-term MRI tracking of intraventricularly-delivered SPIONlabeled UC-BSCs has been demonstrated in a 9-month-old global cerebral ischemia patient. The patient was monitored over 33 months, during which the signal decreased over 4 months and became undetectable at 33 months. ${ }^{179}$

Despite these promising results, MRI is limited by its need for iron-based visualizing agents. These agents can cause false-positive signals from microphages that have engulfed imaging agents, iron being deposited in the brain, or small 
hemorrhage. ${ }^{180}$ Other limitations include poor quantification and sensitivity. ${ }^{171}$ A dual-contrast method, which utilized slow-diffusing SPION and fast-diffusing gadolinium-based chelate-labeling properties, was used to feasibly detect cellular migration and death. ${ }^{175}$ This may advance stem cell therapies by allowing the visualization of transplanted cells' viability and analysis of their in vivo survival. Studies have demonstrated the use of MRI to track micron-sized paramagnetic iron oxide-labeled MSCs injected intranasally to confirm their migration towards glioma xenografts. ${ }^{102} \mathrm{MnEtP}$, a manganese porphyrin contrast agent, also has an excellent sensitivity and specificity for non-invasive stem cell tracking detected by MRI. ${ }^{181}$ MSCs labeled with superparamagnetic iron oxideloaded cationic polymersomes can also be tracked in vivo using MRI. ${ }^{182}$

SPECT radiotracers, particularly indium $111\left({ }^{111} \mathrm{In}\right)$ and technetium-99m ( ${ }^{99 \mathrm{~m} T c)}$ ) as well as PET, are also promising. These methods provide sensitivity in the picomolar range and ability to use the same tracer across multiple species. However, they do not provide anatomical information and must be used in conjunction with $\mathrm{MRI}$, computerized tomography, or X-ray. SPECT imaging has the added benefit of a lower false-positive signaling compared to MRI. ${ }^{27,183}$
Near-infrared (NIR) fluorescence imaging is advantageous over conventional fluorescence imaging due to its improved ability to penetrate tissues. NIR fluorescence imaging was shown to visualize and track the in vivo tumor-targeting process and tissue distribution of intravenously injected MSCs. ${ }^{184}$ This technology may allow the visualization and effective targeting of cells to ischemic tissues.

\section{Clinical translation and future perspectives}

The extensive preclinical literature base would suggest that stem cell therapies for the treatment of ischemic brain injuries are closer to becoming a realistic clinical option. ${ }^{185}$ Several phase I clinical studies have confirmed the safety and feasibility of stem cell therapy in stroke, though efficacy and clinical practicality continue to require refinement. ${ }^{9,186}$

The application of these findings in human studies has led to two approaches in clinical trials: acute administration to prevent ischemic injury secondary to stroke versus late administration in the chronic stroke phase with the goal of promoting neuronal regeneration. A recent phase I trial investigated IV administration of autologous bone marrow mononuclear cells within 24 to
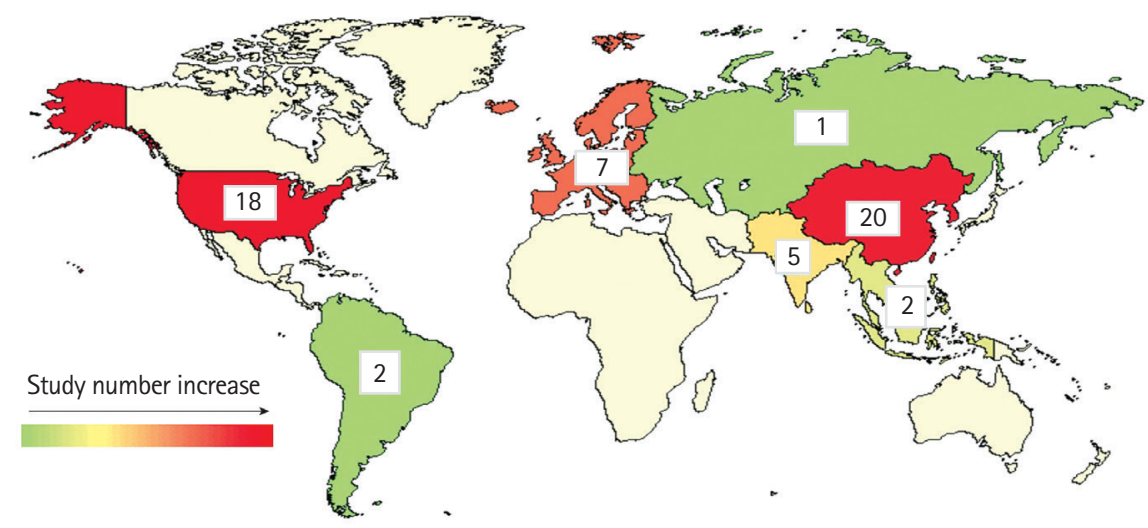

\section{A}
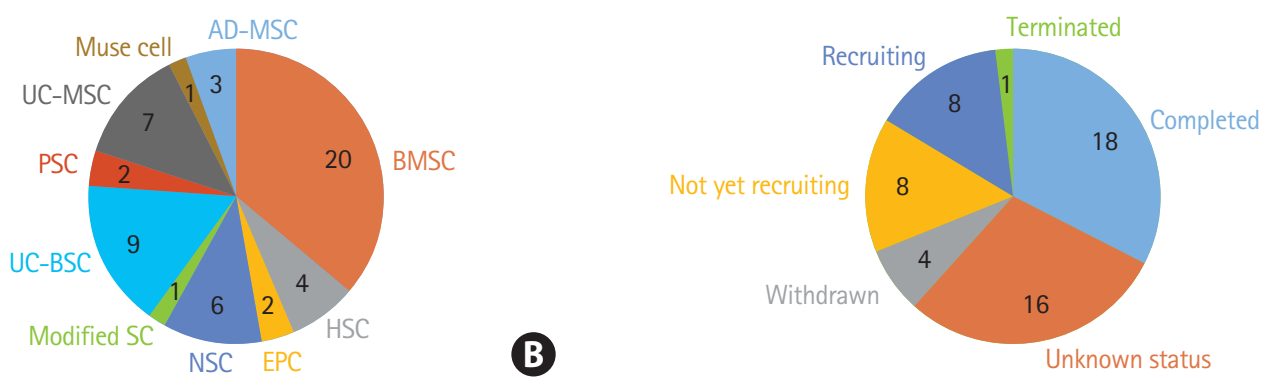

Figure 2. Stem cell therapy clinical trials in ischemic brain injury. (A) Number of clinical trials in the world, (B) according to the stem cell types. Other stem cells including placenta-derived cell, endothelial progenitor cell, hematopoiesis stem cell, muse cells, and modified stem cells, and (C) according to the recruitment status (clinicaltrials.gov, March 2020). UC-MSC, umbilical cord-derived mesenchymal stem cell; PSC, placenta-derived cell; UC-BSC, umbilical cord blood stem cell; SC, stem cell; NSC, neural stem cell; EPC, endothelial progenitor cell; HSC, hematopoietic stem cell; BMSC, bone marrow stem cell; AD-MSC, adipose-derived mesenchymal stem cell. 
72 hours of acute ischemic stroke onset, and patients were followed up for 2 years. No severe adverse effects were detected, thus highlighting the safety of these cells, but the study was not powered for functional outcome effects. ${ }^{13}$ A second trial delivered allogenic BM-MSCs depleted of CD45/glycophorin-A within 48 hours of ischemic stroke and reported a non-significant trend toward improved functional outcomes in the treatment group with no severe adverse events. ${ }^{61}$ In stark contrast to the wealth of preclinical supportive data for this therapy, the largest available phase II randomized controlled trial with blinded endpoint performed in five centers in India found no significant difference in 6-month clinical outcome of ischemic stroke after IV injection of autologous BM-MSCs to 60 acute ischemic stroke patients at a median of 18 days after stroke. ${ }^{4}$ Other studies have investigated the chronic model for stem cell use in stroke management. An open-label pilot trial on 12 chronic stroke patients has demonstrated improved behavioral outcomes 208 weeks following transplant and no adverse immune effects after autologous BMMSCs transplantation, ${ }^{187}$ and a longitudinal trial following patients for 2 years post-NSC transplantation showed improved NIHSS scores and no adverse effects of treatment. ${ }^{45}$

To date, the use of stem cells in the treatment of post-cardiac arrest global cerebral ischemia remains in the animal study phase of investigation and has shown improved neurological functional outcomes in multiple studies of rat cardiac arrest models. Proposed mechanisms include immune/inflammatory modulation, secretion of BDNFs, and BBB integrity protection. ${ }^{123,188}$ The clinical use of therapeutic hypothermia is the only available treatment for neuroprotection following global cerebral ischemia induced by cardiac arrest. ${ }^{189}$ Studies have demonstrated the use of MSCs in conjunction with therapeutic hypothermia after cardiac arrest, thereby reporting increased neuronal survival, BBB protection, reduced oxidative stress, and reduced neutrophilic infiltration. ${ }^{51}$ Given the morbidity and mortality of global cerebral ischemia secondary to cardiac arrest and the paucity of management strategies to improve functional outcomes, MSC treatment should be escalated to larger primate or human models. There are currently no registered clinical trials in this area.

Approximately 55 clinical trials have been registered to investigate the effects of multiple stem cell types, including MSCs derived from the adipose tissue, bone marrow, and umbilical cord, NSCs, hematopoietic stem cells, endothelial progenitor cells, placenta stem cells, multilineage differentiating stress enduring (muse) cells, and modified stem cells on ischemic stroke treatment (https://www.clinicaltrials.gov/) (Figure $2 \mathrm{~A}$ and $\mathrm{B}$ ). Owing to weak support in the clinical data-to-date, studies investigating the optimal timing, dosing, and cellular modifications for improved functional outcomes and reduced infarct burden are imperative. Currently, 19 clinical trials have entered into phase 2, and Figure $2 \mathrm{C}$ summarizes trials that are now under way.

Our review suggests that utilization of novel delivery techniques, particularly intranasal delivery, should garner special attention in the application of stem cell therapy to ischemic brain injury patients and escalation to primate and human studies is warranted. The use of encapsulated scaffolds and cellular preconditioning may also offer advancement in the application of stem cell therapy for these patients (Figure 1).

\section{Conclusions}

Studies continue to optimize stem cell therapies and address the limitations, including the ability to effectively target the CNS, remain therapeutically viable in vivo, and exert beneficial effects while simultaneously avoiding adverse consequences. Novel techniques, such as intranasal delivery, seem promising and need to be validated in adult primates or humans to fully elucidate their potential for stem cell-based therapies. To further advance this field, methods that combine optimal delivery, dosages, preconditioning, and tracking will be needed and should be explored in varying cerebral ischemia models.

\section{Disclosure}

The authors have no financial conflicts of interest.

\section{Acknowledgments}

The work was partially supported by R01HL118084 and R01NS110387 from the National Institutes of Health (NIH) (both to Xiaofeng Jia).

\section{References}

1. Borlongan CV. Concise review: stem cell therapy for stroke patients: are we there yet? Stem Cells Transl Med 2019;8:983988.

2. Banerjee S, Bentley P, Hamady M, Marley S, Davis J, Shlebak $A$, et al. Intra-arterial immunoselected CD34+ stem cells for acute ischemic stroke. Stem Cells Transl Med 2014;3:13221330.

3. Savitz SI, Misra V, Kasam M, Juneja H, Cox CS Jr, Alderman S, et al. Intravenous autologous bone marrow mononuclear cells for ischemic stroke. Ann Neurol 2011;70:59-69.

4. Prasad K, Sharma A, Garg A, Mohanty S, Bhatnagar S, Johri 
$S$, et al. Intravenous autologous bone marrow mononuclear stem cell therapy for ischemic stroke: a multicentric, randomized trial. Stroke 2014;45:3618-3624.

5. Hess DC, Wechsler LR, Clark WM, Savitz SI, Ford GA, Chiu D, et al. Safety and efficacy of multipotent adult progenitor cells in acute ischaemic stroke (MASTERS): a randomised, double-blind, placebo-controlled, phase 2 trial. Lancet Neurol 2017;16:360-368.

6. Krause M, Phan TG, Ma H, Sobey CG, Lim R. Cell-based therapies for stroke: are we there yet? Front Neurol 2019;10:656.

7. Geng W, Tang H, Luo S, Lv Y, Liang D, Kang $X_{1}$ et al. Exosomes from miRNA-126-modified ADSCs promotes functional recovery after stroke in rats by improving neurogenesis and suppressing microglia activation. Am J Transl Res 2019;11:780792.

8. Liu K, Guo L, Zhou Z, Pan M, Yan C. Mesenchymal stem cells transfer mitochondria into cerebral microvasculature and promote recovery from ischemic stroke. Microvasc Res 2019;123: 74-80.

9. Levy ML, Crawford JR, Dib N, Verkh L, Tankovich N, Cramer SC. Phase I/II study of safety and preliminary efficacy of intravenous allogeneic mesenchymal stem cells in chronic stroke. Stroke 2019;50:2835-2841.

10. Gong B, Dong $Y$, He C, Jiang W, Shan $Y$, Zhou BY, et al. Intravenous transplants of human adipose-derived stem cell protect the rat brain from ischemia-induced damage. J Stroke Cerebrovasc Dis 2019;28:595-603.

11. Mangin G, Kubis N. Cell therapy for ischemic stroke: how to turn a promising preclinical research into a successful clinical story. Stem Cell Rev Rep 2019;15:176-193.

12. Spiliopoulos S, Festas G, Reppas L, Brountzos E. Intra-arterial administration of cell-based biological agents for ischemic stroke therapy. Expert Opin Biol Ther 2019;19:249-259.

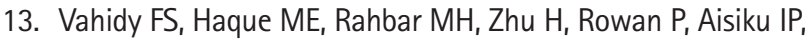
et al. Intravenous bone marrow mononuclear cells for acute ischemic stroke: safety, feasibility, and effect size from a phase I clinical trial. Stem Cells 2019;37:1481-1491.

14. Yu SP, Tung JK, Wei ZZ, Chen D, Berglund K, Zhong W, et al. Optochemogenetic stimulation of transplanted iPS-NPCs enhances neuronal repair and functional recovery after ischemic stroke. J Neurosci 2019;39:6571-6594.

15. Zhang Y, Ma L, Su Y, Su L, Lan X, Wu D, et al. Hypoxia conditioning enhances neuroprotective effects of aged human bone marrow mesenchymal stem cell-derived conditioned medium against cerebral ischemia in vitro. Brain Res 2019;1725:146432.

16. Wang T, Tang W, Sun S, Xu T, Wang H, Guan J, et al. Intravenous infusion of bone marrow mesenchymal stem cells improves brain function after resuscitation from cardiac arrest.
Crit Care Med 2008;36(11 Suppl):S486-S491.

17. Zhou L, Lin Q, Wang P, Yao L, Leong K, Tan Z, et al. Enhanced neuroprotective efficacy of bone marrow mesenchymal stem cells co-overexpressing BDNF and VEGF in a rat model of cardiac arrest-induced global cerebral ischemia. Cell Death Dis 2017;8:e2774.

18. Tang $X$, Chen $F$, Lin $Q$, You $Y$, Ke J, Zhao S. Bone marrow mesenchymal stem cells repair the hippocampal neurons and increase the expression of IGF-1 after cardiac arrest in rats. Exp Ther Med 2017;14:4312-4320.

19. Fairbairn NG, Meppelink AM, Ng-Glazier J, Randolph MA, Winograd JM. Augmenting peripheral nerve regeneration using stem cells: a review of current opinion. World J Stem Cells 2015;7:11-26.

20. Jiang $L_{\text {, Jones }} S_{1}$ Jia $X$. Stem cell transplantation for peripheral nerve regeneration: current options and opportunities. Int J Mol Sci 2017;18:94.

21. Yang $Y$, Ye G, Zhang YL, He HW, Yu BO, Hong YM, et al. Transfer of mitochondria from mesenchymal stem cells derived from induced pluripotent stem cells attenuates hypoxia-ischemia-induced mitochondrial dysfunction in PC12 cells. Neural Regen Res 2020;15:464-472.

22. Deng $Y$, Chen D, Gao F, Lv H, Zhang G, Sun $X$, et al. Exosomes derived from microRNA-138-5p-overexpressing bone marrow-derived mesenchymal stem cells confer neuroprotection to astrocytes following ischemic stroke via inhibition of LCN2. J Biol Eng 2019;13:71.

23. Nalamolu KR, Venkatesh I, Mohandass A, Klopfenstein JD, Pinson DM, Wang DZ, et al. Exosomes treatment mitigates ischemic brain damage but does not improve post-stroke neurological outcome. Cell Physiol Biochem 2019;52:12801291.

24. Qing $L$, Chen $H$, Tang J, Jia $X$. Exosomes and their microRNA cargo: new players in peripheral nerve regeneration. Neurorehabil Neural Repair 2018;32:765-776.

25. Thomi G, Surbek D, Haesler V, Joerger-Messerli M, Schoeberlein A. Exosomes derived from umbilical cord mesenchymal stem cells reduce microglia-mediated neuroinflammation in perinatal brain injury. Stem Cell Res Ther 2019;10:105.

26. Jiang $X$, Fitch $S$, Wang $C$, Wilson $C$, Li J, Grant GA, et al. Nanoparticle engineered TRAIL-overexpressing adipose-derived stem cells target and eradicate glioblastoma via intracranial delivery. Proc Natl Acad Sci U S A 2016;113:1385713862.

27. Li G, Bonamici N, Dey M, Lesniak MS, Balyasnikova IV. Intranasal delivery of stem cell-based therapies for the treatment of brain malignancies. Expert Opin Drug Deliv 2018;15:163172. 
28. Mangraviti A, Tzeng SY, Gullotti D, Kozielski KL, Kim JE, Seng $M$, et al. Non-virally engineered human adipose mesenchymal stem cells produce BMP4, target brain tumors, and extend survival. Biomaterials 2016;100:53-66.

29. Zhang S, Lam KK, Wan JH, Yip CW, Liu HK, Lau QM, et al. Dietary phytochemical approaches to stem cell regulation. $J$ Funct Foods 2020;66:103822.

30. Baker CL, Pera MF. Capturing totipotent stem cells. Cell Stem Cell 2018;22:25-34.

31. Dulak J, Szade K, Szade A, Nowak W, Józkowicz A. Adult stem cells: hopes and hypes of regenerative medicine. Acto Biochim Pol 2015;62:329-337.

32. Jaenisch R, Young R. Stem cells, the molecular circuitry of pluripotency and nuclear reprogramming. Cell 2008;132:567582.

33. Liu Y, Giannopoulou EG, Wen D, Falciatori I, Elemento O, Allis $C D$, et al. Epigenetic profiles signify cell fate plasticity in unipotent spermatogonial stem and progenitor cells. Nat Commun 2016;7:11275.

34. Kooreman NG, Wu JC. Tumorigenicity of pluripotent stem cells: biological insights from molecular imaging. $J R$ Soc $/ n-$ terface 2010;7 Suppl 6:S753-S763.

35. Cefalo MG, Carai A, Miele E, Po A, Ferretti E, Mastronuzzi A, et al. Human iPSC for therapeutic approaches to the nervous system: present and future applications. Stem Cells Int 2016;2016:4869071.

36. Ambasudhan R, Dolatabadi N, Nutter A, Masliah E, Mckercher SR, Lipton SA. Potential for cell therapy in Parkinson's disease using genetically programmed human embryonic stem cellderived neural progenitor cells. J Comp Neurol 2014;522: 2845-2856.

37. Tang $Y, Y u$, Cheng L. Current progress in the derivation and therapeutic application of neural stem cells. Cell Death Dis 2017;8:e3108.

38. Oh JH, Jung CR, Lee MO, Kim J, Son MY. Comparative analysis of human embryonic stem cellderived neural stem cells as an in vitro human model. Int J Mol Med 2018;41:783-790.

39. Cheng $Y$, Zhang J, Deng L, Johnson NR, Yu X, Zhang N, et al. Intravenously delivered neural stem cells migrate into ischemic brain, differentiate and improve functional recovery after transient ischemic stroke in adult rats. Int J Clin Exp Pathol 2015;8:2928-2936.

40. Ryu S, Lee SH, Kim SU, Yoon BW. Human neural stem cells promote proliferation of endogenous neural stem cells and enhance angiogenesis in ischemic rat brain. Neural Regen Res 2016;11:298-304.

41. Huang L, Zhang L. Neural stem cell therapies and hypoxicischemic brain injury. Prog Neurobiol 2019;173:1-17.
42. Andres RH, Horie N, Slikker W, Keren-Gill H, Zhan $K_{1}$ Sun G, et al. Human neural stem cells enhance structural plasticity and axonal transport in the ischaemic brain. Brain 2011;134(Pt 6):17771789.

43. Bacigaluppi M, Pluchino S, Peruzzotti-Jametti L, Kilic E, Kilic $U$, Salani G, et al. Delayed post-ischaemic neuroprotection following systemic neural stem cell transplantation involves multiple mechanisms. Brain 2009;132(Pt 8):2239-2251.

44. Hicks C, Stevanato L, Stroemer RP, Tang E, Richardson S, Sinden JD. In vivo and in vitro characterization of the angiogenic effect of CTX0E03 human neural stem cells. Cell Transplant 2013;22:1541-1552.

45. Kalladka D, Sinden J, Pollock K, Haig C, McLean J, Smith W, et al. Human neural stem cells in patients with chronic ischaemic stroke (PISCES): a phase 1, first-in-man study. Lancet 2016;388:787-796.

46. Zhang R, Zhang Z, Chopp M. Function of neural stem cells in ischemic brain repair processes. J Cereb Blood Flow Metab 2016;36:2034-2043.

47. Barry FP, Murphy JM, O'Brien T, Mahon B. Mesenchymal stem cell transplantation for tissue repair. Semin Plast Surg 2005;19:229-239.

48. Li $X$, Zheng W, Bai $H$, Wang J, Wei $R$, Wen $H$, et al. Intravenous administration of adipose tissue-derived stem cells enhances nerve healing and promotes BDNF expression via the TrkB signaling in a rat stroke model. Neuropsychiatr Dis Treat 2016;12:1287-1293.

49. Donega $\mathrm{V}$, Nijboer $\mathrm{CH}$, van Tilborg G, Dijkhuizen RM, Kavelaars $A$, Heijnen $C J$. Intranasally administered mesenchymal stem cells promote a regenerative niche for repair of neonatal ischemic brain injury. Exp Neurol 2014;261:53-64.

50. Van Velthoven CT, Kavelaars A, Heijnen CJ. Mesenchymal stem cells as a treatment for neonatal ischemic brain damage. Pediatr Res 2012;71(4 Pt 2):474-481.

51. Chung TN, Kim JH, Choi BY, Jeong JY, Chung SP, Kwon SW, et al. Effect of adipose-derived mesenchymal stem cell administration and mild hypothermia induction on delayed neuronal death after transient global cerebral ischemia. Crit Care Med 2017;45:e508-e515.

52. Sugiyama $Y$, Sato $Y$, Kitase $Y$, Suzuki T, Kondo T, Mikrogeorgiou $A$, et al. Intravenous administration of bone marrowderived mesenchymal stem cell, but not adipose tissue-derived stem cell, ameliorated the neonatal hypoxic-ischemic brain injury by changing cerebral inflammatory state in rat. Front Neurol 2018;9:757.

53. Liao L, Shi B, Chang H, Su X, Zhang L, Bi C, et al. Heparin improves BMSC cell therapy: anticoagulant treatment by heparin improves the safety and therapeutic effect of bone mar- 
row-derived mesenchymal stem cell cytotherapy. Theranostics 2017;7:106-116.

54. Liu XL, Zhang W, Tang SJ. Intracranial transplantation of human adipose-derived stem cells promotes the expression of neurotrophic factors and nerve repair in rats of cerebral ischemia-reperfusion injury. Int J Clin Exp Pathol 2013;7:174183.

55. Lam PK, Wang KK, Chin DW, Tong CS, Wang Y, Lo KK, et al. Topically applied adipose-derived mesenchymal stem cell treatment in experimental focal cerebral ischemia. J Clin Neurosci 2020;71:226-233.

56. Ryu B, Sekine H, Homma J, Kobayashi T, Kobayashi E, Kawa-

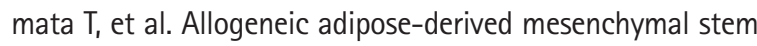
cell sheet that produces neurological improvement with angiogenesis and neurogenesis in a rat stroke model. J Neurosurg 2019;132:442-455.

57. Yang Y, Cai Y, Zhang Y, Liu J, Xu Z. Exosomes secreted by adipose-derived stem cells contribute to angiogenesis of brain microvascular endothelial cells following oxygen-glucose deprivation in vitro through microRNA-181b/TRPM7 axis. J Mol Neurosci 2018;65:74-83.

58. Lin $\mathrm{QM}$, Tang $\mathrm{XH}$, Lin SR, Chen BD, Chen F. Bone marrow-derived mesenchymal stem cell transplantation attenuates overexpression of inflammatory mediators in rat brain after cardiopulmonary resuscitation. Neural Regen Res 2020;15:324331.

59. Vahidinia Z, Azami Tameh A, Nejati M, Beyer C, Talaei SA, Etehadi Moghadam $S$, et al. The protective effect of bone marrow mesenchymal stem cells in a rat model of ischemic stroke via reducing the $\mathrm{C}$-Jun $\mathrm{N}$-terminal kinase expression. Pathol Res Pract 2019;215:152519.

60. Sasaki Y, Sasaki M, Kataoka-Sasaki Y, Nakazaki M, Nagahama $H$, Suzuki J, et al. Synergic effects of rehabilitation and intravenous infusion of mesenchymal stem cells after stroke in rats. Phys Ther 2016;96:1791-1798.

61. Hess DC, Sila CA, Furlan AJ, Wechsler LR, Switzer JA, Mays RW. A double-blind placebo-controlled clinical evaluation of MultiStem for the treatment of ischemic stroke. Int J Stroke 2014;9:381-386.

62. Achyut BR, Varma NR, Arbab AS. Application of umbilical cord blood derived stem cells in diseases of the nervous system. J Stem Cell Res Ther 2014;4:1000202.

63. Zhao O, Hu J, Xiang J, Gu Y, Jin P, Hua F, et al. Intranasal administration of human umbilical cord mesenchymal stem cells-conditioned medium enhances vascular remodeling after stroke. Brain Res 2015;1624:489-496.

64. Liang CC, Liu HL, Chang SD, Chen SH, Lee TH. The protective effect of human umbilical cord blood CD34+ cells and estra- diol against focal cerebral ischemia in female ovariectomized rat: cerebral MR imaging and immunohistochemical study. PLoS One 2016;11:e0147133.

65. Shiao ML, Yuan C, Crane AT, Voth JP, Juliano M, Stone LL, et al. Immunomodulation with human umbilical cord blood stem cells ameliorates ischemic brain injury: a brain transcriptome profiling analysis. Cell Transplant 2019;28:864-873.

66. Gonzales-Portillo GS, Sanberg PR, Franzblau M, GonzalesPortillo C, Diamandis T, Staples M, et al. Mannitol-enhanced delivery of stem cells and their growth factors across the blood-brain barrier. Cell Transplant 2014;23:531-539.

67. Balaguer Rosello A, Bataller L, Lorenzo I, Jarque I, Salavert M, González $E_{\text {, et }}$ al. Infections of the central nervous system after unrelated donor umbilical cord blood transplantation or human leukocyte antigen-matched sibling transplantation. Biol Blood Marrow Transplant 2017;23:134-139.

68. Gutiérrez-Fernández $M$, Rodríguez-Frutos $B$, Ramos-Cejudo J, Teresa Vallejo-Cremades M, Fuentes B, Cerdán S, et al. Effects of intravenous administration of allogenic bone marrow- and adipose tissue-derived mesenchymal stem cells on functional recovery and brain repair markers in experimental ischemic stroke. Stem Cell Res Ther 2013;4:11.

69. Hocum Stone LL, Xiao F, Rotschafer J, Nan Z, Juliano M, Sanberg $C D$, et al. Amelioration of ischemic brain injury in rats with human umbilical cord blood stem cells: mechanisms of action. Cell Transplant 2016;25:1473-1488.

70. Fischer UM, Harting MT, Jimenez F, Monzon-Posadas WO, Xue $\mathrm{H}$, Savitz SI, et al. Pulmonary passage is a major obstacle for intravenous stem cell delivery: the pulmonary first-pass effect. Stem Cells Dev 2009;18:683-692.

71. Jung JW, Kwon M, Choi JC, Shin JW, Park IW, Choi BW, et al. Familial occurrence of pulmonary embolism after intravenous, adipose tissue-derived stem cell therapy. Yonsei Med J 2013;54:1293-1296.

72. Leibacher J, Henschler R. Biodistribution, migration and homing of systemically applied mesenchymal stem/stromal cells. Stem Cell Res Ther 2016;7:7.

73. Anjos-Afonso F, Siapati EK, Bonnet D. In vivo contribution of murine mesenchymal stem cells into multiple cell-types under minimal damage conditions. J Cell Sci 2004;117(Pt 23):56555664.

74. Wang C, Fei Y, Xu C, Zhao Y, Pan Y. Bone marrow mesenchymal stem cells ameliorate neurological deficits and bloodbrain barrier dysfunction after intracerebral hemorrhage in spontaneously hypertensive rats. Int J Clin Exp Pathol 2015;8: 4715-4724.

75. Acosta SA, Tajiri N, Hoover J, Kaneko Y, Borlongan CV. Intravenous bone marrow stem cell grafts preferentially migrate to 
spleen and abrogate chronic inflammation in stroke. Stroke 2015;46:2616-2627.

76. Hammadi AMA, Alhimyari F. Intra-arterial injection of autologous bone marrow-derived mononuclear cells in ischemic stroke patients. Exp Clin Transplant 2019;17(Suppl 1):239241.

77. Liang CC, Lee TH, Chang SD. Effect of umbilical cord blood stem cells transplantation on bladder dysfunction induced by cerebral ischemia in rats. Taiwan J Obstet Gynecol 2016;55: 672-679.

78. Walczak P, Zhang J, Gilad AA, Kedziorek DA, Ruiz-Cabello J, Young RG, et al. Dual-modality monitoring of targeted intraarterial delivery of mesenchymal stem cells after transient ischemia. Stroke 2008;39:1569-1574.

79. Karp JM, Leng Teo GS. Mesenchymal stem cell homing: the devil is in the details. Cell Stem Cell 2009;4:206-216.

80. Sackstein R, Merzaban JS, Cain DW, Dagia NM, Spencer JA, $\mathrm{Lin} C P$, et al. Ex vivo glycan engineering of CD44 programs human multipotent mesenchymal stromal cell trafficking to bone. Nat Med 2008;14:181-187.

81. Cui LL, Kerkelä $E$, Bakreen $A$, Nitzsche F, Andrzejewska $A$, Nowakowski A, et al. The cerebral embolism evoked by intraarterial delivery of allogeneic bone marrow mesenchymal stem cells in rats is related to cell dose and infusion velocity. Stem Cell Res Ther 2015;6:11.

82. Cui LL, Kinnunen T, Boltze J, Nystedt J, Jolkkonen J. Clumping and viability of bone marrow derived mesenchymal stromal cells under different preparation procedures: a flow cytometry-based in vitro study. Stem Cells Int 2016;2016:1764938.

83. Argibay B, Trekker J, Himmelreich U, Beiras A, Topete A, Taboada $P$, et al. Intraarterial route increases the risk of cerebral lesions after mesenchymal cell administration in animal model of ischemia. Sci Rep 2017;7:40758.

84. Cruz-Martinez P, González-Granero S, Molina-Navarro MM, Pacheco-Torres J, Garcia-Verdugo JM, Geijo-Barrientos E, et al. Intraventricular injections of mesenchymal stem cells activate endogenous functional remyelination in a chronic demyelinating murine model. Cell Death Dis 2016;7:e2223.

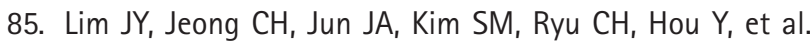
Therapeutic effects of human umbilical cord blood-derived mesenchymal stem cells after intrathecal administration by lumbar puncture in a rat model of cerebral ischemia. Stem Cell Res Ther 2011;2:38.

86. Al Fauzi A, Sumorejo P, Suroto NS, Parenrengi MA, Wahyuhadi J, Turchan $A$, et al. Clinical outcomes of repeated intraventricular transplantation of autologous bone marrow mesenchymal stem cells in chronic haemorrhagic stroke: a oneyear follow up. Open Neurol J 2017;11:74-83.
87. Fauzi AA, Suroto NS, Bajamal AH, Machfoed MH. Intraventricular transplantation of autologous bone marrow mesenchymal stem cells via ommaya reservoir in persistent vegetative state patients after haemorrhagic stroke: report of two cases \& review of the literature. J Stem Cells Regen Med 2016;12:100104.

88. Wang Z, Yang $X$, He J, Du J, Liu S, Jia X. Intracerebroventricular administration of neural stem cells after cardiac arrest. Conf Proc IEEE Eng Med Biol Soc 2019;2019:4213-4216.

89. Bazhanov N, Ylostalo JH, Bartosh TJ, Tiblow A, Mohammadipoor A, Foskett $A$, et al. Intraperitoneally infused human mesenchymal stem cells form aggregates with mouse immune cells and attach to peritoneal organs. Stem Cell Res Ther 2016;7:27.

90. Zhang X, Zhang O, Li W, Nie D, Chen W, Xu C, et al. Therapeutic effect of human umbilical cord mesenchymal stem cells on neonatal rat hypoxic-ischemic encephalopathy. $J$ Neurosci Res 2014;92:35-45.

91. Cheng Z, Wang L, Qu M, Liang H, Li W, Li Y, et al. Mesenchymal stem cells attenuate blood-brain barrier leakage after cerebral ischemia in mice. J Neuroinflammation 2018;15:135.

92. Van Velthoven CT, Kavelaars A, van Bel F, Heijnen CJ. Mesenchymal stem cell treatment after neonatal hypoxic-ischemic brain injury improves behavioral outcome and induces neuronal and oligodendrocyte regeneration. Brain Behav Immun 2010;24:387-393.

93. Chen SJ, Chang CM, Tsai SK, Chang YL, Chou SJ, Huang SS, et al. Functional improvement of focal cerebral ischemia injury by subdural transplantation of induced pluripotent stem cells with fibrin glue. Stem Cells Dev 2010;19:1757-1767.

94. Baker EW, Platt SR, Lau WW, Grace HE, Holmes SP, Wang L, et al. Induced pluripotent stem cell-derived neural stem cell therapy enhances recovery in an ischemic stroke pig model. Sci Rep 2017;7:10075.

95. Trapp T, Kögler G, El-Khattouti A, Sorg RV, Besselmann M, Föcking $M$, et al. Hepatocyte growth factor/c-MET axis-mediated tropism of cord blood-derived unrestricted somatic stem cells for neuronal injury. J Biol Chem 2008;283:3224432253.

96. Wagenaar $\mathrm{N}$, Nijboer $\mathrm{CH}$, van Bel F. Repair of neonatal brain injury: bringing stem cell-based therapy into clinical practice. Dev Med Child Neurol 2017;59:997-1003.

97. Cunningham MG, Bolay $H$, Scouten CW, Moore $C$, Jacoby $D$, Moskowitz $\mathrm{M}$, et al. Preclinical evaluation of a novel intracerebral microinjection instrument permitting electrophysiologically guided delivery of therapeutics. Neurosurgery 2004;54:1497-1507.

98. Danielyan $L$, Schäfer $R$, von Ameln-Mayerhofer A, Buadze $M$, 
Geisler J, Klopfer T, et al. Intranasal delivery of cells to the brain. Eur J Cell Biol 2009;88:315-324.

99. Galeano C, Qiu Z, Mishra A, Farnsworth SL, Hemmi JJ, Moreira $A$, et al. The route by which intranasally delivered stem cells enter the central nervous system. Cell Transplant 2018;27: 501-514.

100. Yu D, Li G, Lesniak MS, Balyasnikova IV. Intranasal delivery of therapeutic stem cells to glioblastoma in a mouse model. $J$ Vis Exp 2017;124:55845.

101. Danielyan L, Beer-Hammer S, Stolzing A, Schäfer R, Siegel G,

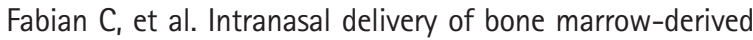
mesenchymal stem cells, macrophages, and microglia to the brain in mouse models of Alzheimer's and Parkinson's disease. Cell Transplant 2014;23 Suppl 1:S123-S139.

102. Balyasnikova IV, Prasol MS, Ferguson SD, Han Y, Ahmed AU, Gutova $M$, et al. Intranasal delivery of mesenchymal stem cells significantly extends survival of irradiated mice with experimental brain tumors. Mol Ther 2014;22:140-148.

103. Chau MJ, Deveau TC, Gu X, Kim YS, Xu Y, Yu SP, et al. Delayed and repeated intranasal delivery of bone marrow stromal cells increases regeneration and functional recovery after ischemic stroke in mice. BMC Neurosci 2018;19:20.

104. Dey M, Yu D, Kanojia D, Li G, Sukhanova M, Spencer DA, et al. Intranasal oncolytic virotherapy with CXCR4-enhanced stem cells extends survival in mouse model of glioma. Stem Cell Reports 2016;7:471-482.

105. Donega $\mathrm{V}$, van Velthoven $\mathrm{CT}$, Nijboer $\mathrm{CH}$, van Bel F, Kas MJ, Kavelaars $A$, et al. Intranasal mesenchymal stem cell treatment for neonatal brain damage: long-term cognitive and sensorimotor improvement. PLoS One 2013;8:e51253.

106. Li YH, Feng L, Zhang GX, Ma CG. Intranasal delivery of stem cells as therapy for central nervous system disease. Exp Mol Pathol 2015;98:145-151.

107. Wei N, Yu SP, Gu X, Taylor TM, Song D, Liu XF, et al. Delayed intranasal delivery of hypoxic-preconditioned bone marrow mesenchymal stem cells enhanced cell homing and therapeutic benefits after ischemic stroke in mice. Cell Transplant 2013;22:977-991.

108. Ji G, Liu M, Zhao XF, Liu XY, Guo QL, Guan ZF, et al. NF-KB signaling is involved in the effects of intranasally engrafted human neural stem cells on neurofunctional improvements in neonatal rat hypoxic-ischemic encephalopathy. CNS Neurosci Ther 2015;21:926-935.

109. Wei ZZ, Gu X, Ferdinand $A$, Lee JH, Ji X, Ji XM, et al. Intranasal delivery of bone marrow mesenchymal stem cells improved neurovascular regeneration and rescued neuropsychiatric deficits after neonatal stroke in rats. Cell Transplant 2015;24:391-402.
110. Ohshima M, Taguchi A, Tsuda $H$, Sato $Y$, Yamahara $K$, Harada-Shiba $\mathrm{M}$, et al. Intraperitoneal and intravenous deliveries are not comparable in terms of drug efficacy and cell distribution in neonatal mice with hypoxia-ischemia. Brain Dev 2015;37:376-386.

111. Sarmah D, Agrawal V, Rane P, Bhute S, Watanabe M, Kalia K, et al. Mesenchymal stem cell therapy in ischemic stroke: a meta-analysis of preclinical studies. Clin Pharmacol Ther 2018;103:990-998.

112. Jha AK, Tharp KM, Ye J, Santiago-Ortiz JL, Jackson WM, Stahl $A$, et al. Enhanced survival and engraftment of transplanted stem cells using growth factor sequestering hydrogels. Biomaterials 2015;47:1-12.

113. Hwang NS, Varghese $S$, Elisseeff J. Controlled differentiation of stem cells. Adv Drug Deliv Rev 2008;60:199-214.

114. Stone LL, Grande A, Low WC. Neural repair and neuroprotection with stem cells in ischemic stroke. Brain Sci 2013;3:599614.

115. Jian WH, Wang HC, Kuan $\mathrm{CH}$, Chen $\mathrm{MH}, \mathrm{Wu} \mathrm{HC}$, Sun JS, et al. Glycosaminoglycan-based hybrid hydrogel encapsulated with polyelectrolyte complex nanoparticles for endogenous stem cell regulation in central nervous system regeneration. Biomaterials 2018;174:17-30.

116. Liu S, Zhou J, Zhang X, Liu Y, Chen J, Hu B, et al. Strategies to optimize adult stem cell therapy for tissue regeneration. Int $\mathrm{J}$ Mol Sci 2016;17:982.

117. Vu O, Xie K, Eckert M, Zhao W, Cramer SC. Meta-analysis of preclinical studies of mesenchymal stromal cells for ischemic stroke. Neurology 2014;82:1277-1286.

118. Lin W, Hsuan YC, Lin MT, Kuo TW, Lin CH, Su YC, et al. Human umbilical cord mesenchymal stem cells preserve adult newborn neurons and reduce neurological injury after cerebral ischemia by reducing the number of hypertrophic microglia/macrophages. Cell Transplant 2017;26:1798-1810.

119. Satani N, Cai C, Giridhar K, McGhiey D, George S, Parsha K, et al. World-wide efficacy of bone marrow derived mesenchymal stromal cells in preclinical ischemic stroke models: systematic review and meta-analysis. Front Neurol 2019;10:405.

120. Wei L, Wei ZZ, Jiang MQ, Mohamad O, Yu SP. Stem cell transplantation therapy for multifaceted therapeutic benefits after stroke. Prog Neurobiol 2017;157:49-78.

121. Saenger AK, Christenson RH. Stroke biomarkers: progress and challenges for diagnosis, prognosis, differentiation, and treatment. Clin Chem 2010;56:21-33.

122. Reis C, Akyol O, Araujo C, Huang L, Enkhjargal B, Malaguit J, et al. Pathophysiology and the monitoring methods for cardiac arrest associated brain injury. Int J Mol Sci 2017;18:129.

123. Chung TN, Kim JH, Choi BY, Chung SP, Kwon SW, Suh SW. 
Adipose-derived mesenchymal stem cells reduce neuronal death after transient global cerebral ischemia through prevention of blood-brain barrier disruption and endothelial damage. Stem Cells Transl Med 2015;4:178-185.

124. Yu Y, Wang D, Li H, Fan J, Liu Y, Zhao X, et al. Mesenchymal stem cells derived from induced pluripotent stem cells play a key role in immunomodulation during cardiopulmonary resuscitation. Brain Res 2019;1720:146293.

125. Lin QM, Zhao S, Zhou LL, Fang XS, Fu Y, Huang ZT. Mesenchymal stem cells transplantation suppresses inflammatory responses in global cerebral ischemia: contribution of TNFa-induced protein 6. Acta Pharmacol Sin 2013;34:784-792.

126. Wang JW, Qiu YR, Fu Y, Liu J, He Z, Huang ZT. Transplantation with hypoxia-preconditioned mesenchymal stem cells suppresses brain injury caused by cardiac arrest-induced global cerebral ischemia in rats. J Neurosci Res 2017;95:2059-2070.

127. Hirko $A C$, Dallasen $R$, Jomura $S, X u Y$. Modulation of inflammatory responses after global ischemia by transplanted umbilical cord matrix stem cells. Stem Cells 2008;26:28932901.

128. Yamaguchi $S$, Horie $N$, Satoh $K$, Ishikawa $T$, Mori $T$, Maeda $H_{\text {, }}$ et al. Age of donor of human mesenchymal stem cells affects structural and functional recovery after cell therapy following ischaemic stroke. J Cereb Blood Flow Metab 2018;38:11991212.

129. Dimmeler S, Vasa-Nicotera M. Aging of progenitor cells: limitation for regenerative capacity? J Am Coll Cardiol 2003;42: 2081-2082.

130. Khan M, Mohsin S, Khan SN, Riazuddin S. Repair of senescent myocardium by mesenchymal stem cells is dependent on the age of donor mice. J Cell Mol Med 2011;15:1515-1527.

131. Sart S, Ma T, Li Y. Preconditioning stem cells for in vivo delivery. Biores Open Access 2014;3:137-149.

132. Ejtehadifar M, Shamsasenjan K, Movassaghpour A, Akbarza-

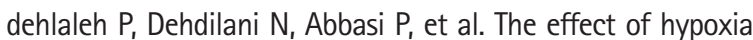
on mesenchymal stem cell biology. Adv Pharm Bull 2015;5: 141-149.

133. Vertelov G, Kharazi L, Muralidhar MG, Sanati G, Tankovich T, Kharazi A. High targeted migration of human mesenchymal stem cells grown in hypoxia is associated with enhanced activation of RhoA. Stem Cell Res Ther 2013;4:5.

134. Horie N, Pereira MP, Niizuma K, Sun G, Keren-Gill H, Encarnacion $A$, et al. Transplanted stem cell-secreted vascular endothelial growth factor effects poststroke recovery, inflammation, and vascular repair. Stem Cells 2011;29:274-285.

135. Van Velthoven CT, Sheldon RA, Kavelaars A, Derugin N, Vexler $\mathrm{ZS}$, Willemen $\mathrm{HL}$, et al. Mesenchymal stem cell transplantation attenuates brain injury after neonatal stroke. Stroke
2013;44:1426-1432.

136. Ou Y, Yu S, Kaneko Y, Tajiri N, Bae EC, Chheda SH, et al. Intravenous infusion of GDNF gene-modified human umbilical cord blood CD34+ cells protects against cerebral ischemic injury in spontaneously hypertensive rats. Brain Res 2010;1366:217225.

137. Eckenstein FP, Andersson C, Kuzis K, Woodward WR. Distribution of acidic and basic fibroblast growth factors in the mature, injured and developing rat nervous system. Prog Brain Res 1994;103:55-64.

138. Benz AH, Shajari M, Peruzki N, Dehghani F, Maronde E. Early growth response-1 induction by fibroblast growth factor-1 via increase of mitogen-activated protein kinase and inhibition of protein kinase $B$ in hippocampal neurons. Br J Pharmacol 2010;160:1621-1630.

139. Tsai MJ, Tsai SK, Huang MC, Liou DY, Huang SL, Hsieh WH, et al. Acidic FGF promotes neurite outgrowth of cortical neurons and improves neuroprotective effect in a cerebral ischemic rat model. Neuroscience 2015;305:238-247.

140. Ghazavi H, Hoseini SJ, Ebrahimzadeh-Bideskan A, Mashkani $B$, Mehri $S$, Ghorbani $A$, et al. Fibroblast growth factor type 1 (FGF1)-overexpressed adipose-derived mesenchaymal stem cells (AD-MSC FGF1) induce neuroprotection and functional recovery in a rat stroke model. Stem Cell Rev Rep 2017;13: 670-685

141. Fatt M, Hsu K, He L, Wondisford F, Miller FD, Kaplan DR, et al. Metformin acts on two different molecular pathways to enhance adult neural precursor proliferation/self-renewal and differentiation. Stem Cell Reports 2015;5:988-995.

142. Liu Y, Tang G, Zhang Z, Wang Y, Yang GY. Metformin promotes focal angiogenesis and neurogenesis in mice following middle cerebral artery occlusion. Neurosci Lett 2014;579:4651.

143. Li J, Benashski SE, Venna VR, McCullough LD. Effects of metformin in experimental stroke. Stroke 2010;41:2645-2652.

144. Jiang T, Yu JT, Zhu XC, Wang HF, Tan MS, Cao L, et al. Acute metformin preconditioning confers neuroprotection against focal cerebral ischaemia by pre-activation of AMPK-dependent autophagy. Br J Pharmacol 2014;171:3146-3157.

145. Ould-Brahim F, Sarma SN, Syal C, Lu KJ, Seegobin M, Carter $A$, et al. Metformin preconditioning of human induced pluripotent stem cell-derived neural stem cells promotes their engraftment and improves post-stroke regeneration and recovery. Stem Cells Dev 2018;27:1085-1096.

146. Yrjänheikki J, Tikka $T$, Keinänen $R$, Goldsteins $G$, Chan PH, Koistinaho J. A tetracycline derivative, minocycline, reduces inflammation and protects against focal cerebral ischemia with a wide therapeutic window. Proc Natl Acad Sci U S A 
1999;96:13496-13500.

147. Sakata H, Niizuma $K$, Yoshioka $H$, Kim GS, Jung JE, Katsu M, et al. Minocycline-preconditioned neural stem cells enhance neuroprotection after ischemic stroke in rats: version 2. J Neurosci 2012;32:3462-3473.

148. Franco EC, Cardoso MM, Gouvêia A, Pereira A, Gomes-Leal $W$. Modulation of microglial activation enhances neuroprotection and functional recovery derived from bone marrow mononuclear cell transplantation after cortical ischemia. Neurosci Res 2012;73:122-132.

149. Sharma RK, Zhou Q, Netland PA. Effect of oxidative preconditioning on neural progenitor cells. Brain Res 2008;1243:19-26.

150. George PM, Bliss TM, Hua T, Lee $A$, Oh B, Levinson $A$, et al. Electrical preconditioning of stem cells with a conductive polymer scaffold enhances stroke recovery. Biomaterials 2017;142:31-40.

151. Moon GJ, Cho YH, Kim DH, Sung JH, Son JP, Kim S, et al. Serum-mediated activation of bone marrow-derived mesenchymal stem cells in ischemic stroke patients: a novel preconditioning method. Cell Transplant 2018;27:485-500.

152. Yu SP, Wei Z, Wei L. Preconditioning strategy in stem cell transplantation therapy. Trans/ Stroke Res 2013;4:76-88.

153. Wei W, Wu D, Duan Y, Elkin KB, Chandra A, Guan L, et al. Neuroprotection by mesenchymal stem cell (MSC) administration is enhanced by local cooling infusion ( $\mathrm{LCl})$ in ischemia. Brain Res 2019;1724:146406.

154. Hwang S, Choi J, Kim M. Combining human umbilical cord blood cells with erythropoietin enhances angiogenesis/neurogenesis and behavioral recovery after stroke. Front Neurol 2019;10:357.

155. Karakoti A, Singh S, Dowding JM, Seal S, Self WT. Redox-active radical scavenging nanomaterials. Chem Soc Rev 2010;39: 4422-4432.

156. Zuo L, Feng $\mathrm{Q}$, Han Y, Chen M, Guo M, Liu Z, et al. Therapeutic effect on experimental acute cerebral infarction is enhanced after nanoceria labeling of human umbilical cord mesenchymal stem cells. Ther Adv Neurol Disord 2019;12:1756286419859725.

157. Choi C, Kim HM, Shon J, Park J, Kim HT, Kang SH, et al. The combination of mannitol and temozolomide increases the effectiveness of stem cell treatment in a chronic stroke model. Cytotherapy 2018;20:820-829.

158. Shen WB, Anastasiadis P, Nguyen B, Yarnell D, Yarowsky PJ, Frenkel $V$, et al. Magnetic enhancement of stem cell-targeted delivery into the brain following MR-guided focused ultrasound for opening the blood-brain barrier. Cell Transplant 2017;26:1235-1246.

159. Tollemar V, Collier ZJ, Mohammed MK, Lee MJ, Ameer GA, Reid RR. Stem cells, growth factors and scaffolds in cranio- facial regenerative medicine. Genes Dis 2016;3:56-71.

160. Luo L, Albashari AA, Wang $X$, Jin L, Zhang Y, Zheng $L$, et al. Effects of transplanted heparin-poloxamer hydrogel combining dental pulp stem cells and bFGF on spinal cord injury repair. Stem Cells Int 2018;2018:2398521.

161. Kang P, Kumar S, Schaffer D. Novel biomaterials to study neural stem cell mechanobiology and improve cell-replacement therapies. Curr Opin Biomed Eng 2017;4:13-20.

162. Bolan F, Louca I, Heal C, Cunningham CJ. The potential of biomaterial-based approaches as therapies for ischemic stroke: a systematic review and meta-analysis of pre-clinical studies. Front Neurol 2019;10:924.

163. Payne SL, Tuladhar A, Obermeyer JM, Varga BV, Teal CJ, Morshead $\mathrm{CM}$, et al. Initial cell maturity changes following transplantation in a hyaluronan-based hydrogel and impacts therapeutic success in the stroke-injured rodent brain. Biomaterials 2019;192:309-322.

164. Tseng TC, Tao L, Hsieh FY, Wei Y, Chiu IM, Hsu SH. An injectable, self-healing hydrogel to repair the central nervous system. Adv Mater 2015;27:3518-3524.

165. Jin $K_{1}$ Mao X, Xie L, Galvan V, Lai B, Wang Y, et al. Transplantation of human neural precursor cells in Matrigel scaffolding improves outcome from focal cerebral ischemia after delayed postischemic treatment in rats. J Cereb Blood Flow Metab 2010;30:534-544.

166. González-Nieto D, Fernández-García L, Pérez-Rigueiro J, Guinea GV, Panetsos F. Hydrogels-assisted cell engraftment for repairing the stroke-damaged brain: chimera or reality. Polymers (Basel) 2018;10:184.

167. Zhuo F, Liu X, Gao O, Wang Y, Hu K, Cai O. Injectable hyaluronan-methylcellulose composite hydrogel crosslinked by polyethylene glycol for central nervous system tissue engineering. Mater Sci Eng C Mater Biol App/ 2017;81:1-7.

168. Ballios BG, Cooke MJ, Donaldson L, Coles BL, Morshead CM, van der Kooy $D$, et al. A hyaluronan-based injectable hydrogel improves the survival and integration of stem cell progeny following transplantation. Stem Cell Reports 2015;4:1031-1045.

169. Zhong J, Chan A, Morad L, Kornblum HI, Fan G, Carmichael ST. Hydrogel matrix to support stem cell survival after brain transplantation in stroke. Neurorehabil Neural Repair 2010;24:636644.

170. Wollenberg AL, O'Shea TM, Kim JH, Czechanski A, Reinholdt $L G$, Sofroniew MV, et al. Injectable polypeptide hydrogels via methionine modification for neural stem cell delivery. Biomaterials 2018;178:527-545.

171. Wolfs E, Verfaillie CM, van Laere K, Deroose CM. Radiolabeling strategies for radionuclide imaging of stem cells. Stem Cell Rev Rep 2015;11:254-274. 
172. Zhang $F$, Duan $X$, Lu L, Zhang $X$, Chen $M$, Mao J, et al. In vivo long-term tracking of neural stem cells transplanted into an acute ischemic stroke model with reporter gene-based bimodal MR and optical imaging. Cell Transplant 2017;26:16481662.

173. Holvoet B, De Waele L, Quattrocelli M, Gheysens O, Sampaolesi $M$, Verfaillie $C M$, et al. Increased understanding of stem cell behavior in neurodegenerative and neuromuscular disorders by use of noninvasive cell imaging. Stem Cells Int 2016;2016:6235687.

174. Ma N, Cheng H, Lu M, Liu O, Chen X, Yin G, et al. Magnetic resonance imaging with superparamagnetic iron oxide fails to track the long-term fate of mesenchymal stem cells transplanted into heart. Sci Rep 2015;5:9058.

175. Ngen EJ, Wang L, Kato Y, Krishnamachary B, Zhu W, Gandhi $\mathrm{N}$, et al. Imaging transplanted stem cells in real time using an MRI dual-contrast method. Sci Rep 2015;5:13628.

176. Shen WB, Plachez $C$, Chan A, Yarnell D, Puche AC, Fishman $P S$, et al. Human neural progenitor cells retain viability, phenotype, proliferation, and lineage differentiation when labeled with a novel iron oxide nanoparticle, Molday ION Rhodamine B. Int J Nanomedicine 2013;8:4593-4600.

177. Shen WB, Plachez C, Tsymbalyuk O, Tsymbalyuk N, Xu S, Smith $A M$, et al. Cell-based therapy in TBI: magnetic retention of neural stem cells in vivo. Cell Transplant 2016;25:1085-1099.

178. Walczak P, Wojtkiewicz J, Nowakowski A, Habich A, Holak $P_{1}$ $\mathrm{Xu}$ J, et al. Real-time MRI for precise and predictable intraarterial stem cell delivery to the central nervous system. $J$ Cereb Blood Flow Metab 2017;37:2346-2358.

179. Janowski M, Walczak P, Kropiwnicki T, Jurkiewicz E, Domanska-Janik K, Bulte JW, et al. Long-term MRI cell tracking after intraventricular delivery in a patient with global cerebral ischemia and prospects for magnetic navigation of stem cells within the CSF. PLoS One 2014;9:e97631.

180. Li W, Chen R, Lv J, Wang H, Liu Y, Peng Y, et al. In vivo photoacoustic imaging of brain injury and rehabilitation by high-efficient near-infrared dye labeled mesenchymal stem cells with enhanced brain barrier permeability. Adv Sci (Weinh)
2017;5:1700277.

181. Haedicke IE, Loai S, Cheng HM. An efficient T1 contrast agent for labeling and tracking human embryonic stem cells on MRI. Contrast Media Mol Imaging 2019;2019:3475786.

182. Duan $X$, Wang $Y$, Zhang F, Lu L, Cao M, Lin B, et al. Superparamagnetic iron oxide-loaded cationic polymersomes for cellular MR imaging of therapeutic stem cells in stroke. $J$ Biomed Nanotechnol 2016;12:2112-2124.

183. Cheng SH, Yu D, Tsai HM, Morshed RA, Kanojia D, Lo LW, et al. Dynamic in vivo SPECT imaging of neural stem cells functionalized with radiolabeled nanoparticles for tracking of glioblastoma. J Nucl Med 2016;57:279-284.

184. Kim SM, Jeong CH, Woo JS, Ryu CH, Lee JH, Jeun SS. In vivo near-infrared imaging for the tracking of systemically delivered mesenchymal stem cells: tropism for brain tumors and biodistribution. Int J Nanomedicine 2015;11:13-23.

185. Gervois $P$, Wolfs $E$, Ratajczak J, Dillen $Y$, Vangansewinkel $T$, Hilkens $P$, et al. Stem cell-based therapies for ischemic stroke: preclinical results and the potential of imaging-assisted evaluation of donor cell fate and mechanisms of brain regeneration. Med Res Rev 2016;36:1080-1126.

186. Nagpal A, Choy FC, Howell S, Hillier S, Chan F, HamiltonBruce $M A$, et al. Safety and effectiveness of stem cell therapies in early-phase clinical trials in stroke: a systematic review and meta-analysis. Stem Cell Res Ther 2017;8:191.

187. Bhasin A, Kumaran SS, Bhatia R, Mohanty S, Srivastava MV. Safety and feasibility of autologous mesenchymal stem cell transplantation in chronic stroke in Indian patients: a fouryear follow up. J Stem Cells Regen Med 2017;13:14-19.

188. Zheng W, Honmou O, Miyata K, Harada K, Suzuki J, Liu H, et al. Therapeutic benefits of human mesenchymal stem cells derived from bone marrow after global cerebral ischemia. Brain Res 2010;1310:8-16.

189. Field JM, Hazinski MF, Sayre MR, Chameides L, Schexnayder SM, Hemphill R, et al. Part 1: executive summary: 2010 American Heart Association Guidelines for Cardiopulmonary Resuscitation and Emergency Cardiovascular Care. Circulation 2010;122(18 Suppl 3):S640-S656. 